Article

\title{
Chain Substituted Cannabilactones with Selectivity for the CB2 Cannabinoid Receptor
}

\author{
Shakiru O. Alapafuja ${ }^{1}$, Spyros P. Nikas ${ }^{1, *(\mathbb{O}}$, Thanh C. Ho ${ }^{1}{ }^{\mathbb{O}}$, Fei Tong ${ }^{1}$, Othman Benchama ${ }^{1}$ \\ and Alexandros Makriyannis ${ }^{1,2, *}$ \\ 1 Center for Drug Discovery and Department of Pharmaceutical Sciences, Northeastern University, \\ Boston, MA 02115, USA; s.alapafuja@northeastern.edu (S.O.A.); t.ho@northeastern.edu (T.C.H.); \\ tong.f@husky.neu.edu (F.T.); othmanb@gmail.com (O.B.) \\ 2 Department of Chemistry \& Chemical Biology, Northeastern University, Boston, MA 02115, USA \\ * Correspondence: s.nikas@northeastern.edu (S.P.N.); a.makriyannis@northeastern.edu (A.M.); \\ Tel.: +1617-373-3125 (S.P.N.); +1617-373-4200 (A.M.)
}

Academic Editor: Spyros P. Nikas

Received: 23 July 2019; Accepted: 27 September 2019; Published: 1 October 2019

\begin{abstract}
In earlier work, we reported a novel class of CB2 selective ligands namely cannabilactones. These compounds carry a dimethylheptyl substituent at $\mathrm{C} 3$, which is typical for synthetic cannabinoids. In the current study with the focus on the pharmacophoric side chain at C3 we explored the effect of replacing the $\mathrm{C1}^{\prime}$-gem-dimethyl group with the bulkier cyclopentyl ring, and, we also probed the chain's length and terminal carbon substitution with bromo or cyano groups. One of the analogs synthesized namely 6-[1-(1,9-dihydroxy-6-oxo-6H-benzo[c]chromen-3-yl) cyclopentyl] hexanenitrile (AM4346) has very high affinity $\left(K_{\mathrm{i}}=4.9 \mathrm{nM}\right)$ for the mouse CB2 receptor (mCB2) and 131-fold selectivity for that target over the rat CB1 (rCB1). The species difference in the affinities of AM4346 between the mouse (m) and the human (h) CB2 receptors is reduced when compared to our first-generation cannabilactones. In the cyclase assay, our lead compound was found to be a highly potent and efficacious hCB2 receptor agonist $\left(\mathrm{EC}_{50}=3.7 \pm 1.5 \mathrm{nM}, E_{(\max )}=89 \%\right)$. We have also extended our structure-activity relationship (SAR) studies to include biphenyl synthetic intermediates that mimic the structure of the phytocannabinoid cannabinodiol.
\end{abstract}

Keywords: cannabinoid receptors; CB2 selective ligands; synthesis; cannabilactones; structure-activity relationship studies

\section{Introduction}

The two G-protein coupled receptors (GPCRs) termed cannabinoid receptor 1 (CB1) and cannabinoid receptor 2 (CB2) are principal components of the endocannabinoid biosignaling system and molecular targets for the psychoactive constituent of cannabis $\Delta^{9}$-tetrahydrocannabinol $\left(\Delta^{9}\right.$-THC) [1-3]. Both CB1 and CB2 also bind the FDA approved drug Nabilone and many other exogenous (plant-derived and synthetic) cannabinoids. The CB1 receptor retains a high $(\geq 97 \%)$ degree of amino acid sequence identity across mouse, rat, and human [4]. In contrast, the human CB2 receptor displays only $82 \%$ and $81 \%$ amino acid identity with mouse [5] and rat [6] respectively. The CB1 receptor was found to be localized primarily in the brain and it is one of the most abundant GPCRs in the central nervous system (CNS) [4]. This receptor is also found in peripheral tissues and organs [7]. Activation of the central CB1 receptors mediates most of the cannabinoid psychotropic and behavioral effects. Conversely, the CB2 receptors are detectable at very low levels in brain and they are expressed predominantly in immune cells and in the periphery [8]. Nevertheless, the CB2 receptors may be induced in the CNS under pathologic conditions. Collaborative efforts, including our laboratory, have led to the first crystal structures of the agonist and antagonist bound human CB1, while recently we published the first crystal structure of the 
human CB2 receptor in a complex with the antagonist AM10257. This breakthrough work provides a molecular basis for predicting the binding modes of cannabinoids with their target proteins, and offers invaluable information for target-based drug design [9-12].

Selective CB2 receptor activation is a very promising method of modulating the endocannabinoid system because the pharmacologic effects are devoid of centrally mediated liabilities that are correlated with CB1 receptor modulation either directly by exogenous cannabinoids or indirectly through functional interactions with other receptor systems [13]. Selective CB2 activation would decrease CB1 associated ataxia, hypothermia, mood and memory disturbances, and abuse potential [14-19]. Currently, the CB2 receptor has emerged as an attractive therapeutic target for the treatment of inflammatory and neuropathic pain, as well as neurodegenerative disorders [20-23], and cancer [24-26].

Our group has identified the cannabilactones (Figure 1), as a new class of CB2 agonists with structural similarities to the 6,6-dimethyl counterpart and phytocannabinoid cannabinol (Figure 2). Two first generation analogs within this class of compounds namely AM1714 and AM1710 (Figure 1) have become important pharmacological tools in establishing proof of concept for the usefulness of the CB2 receptor activation approach [27-33]. Both these CB2 selective agonists are found to possess potent peripheral analgesic activity in several animal models of inflammatory and neuropathic pain. Moreover, functional studies with a lead compound have highlighted the potential of the cannabilactone based CB2 agonists to behave as neutral antagonists/low potency inverse agonists at CB1, a unique property which imparts very high functional selectivity for CB2 over CB1 [30,31,33]. Thus, from a medicinal chemistry perspective, the class of cannabilactone compounds remains an attractive structural motif for further development of CB2 selective and efficacious agonists.

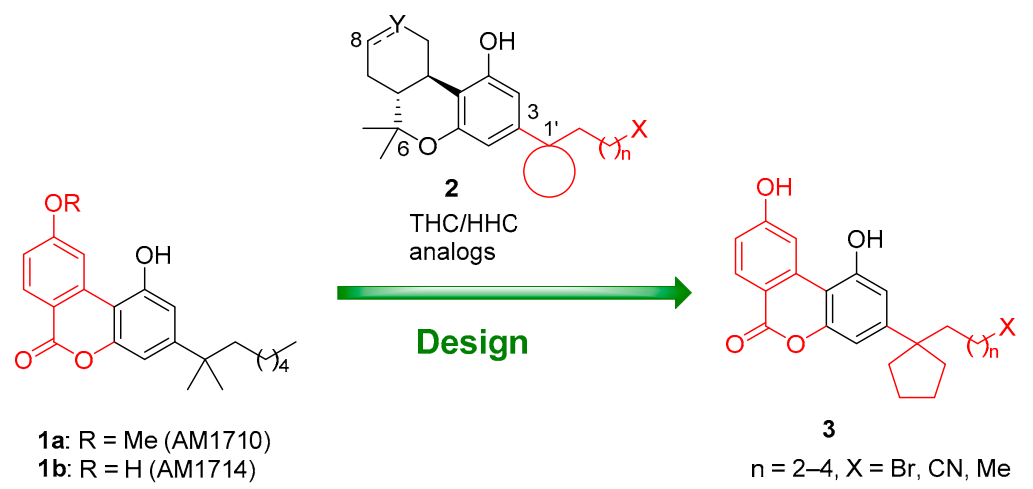

Figure 1. Design of chain substituted cannabilactones and structures of the first-generation analogs AM1710 and AM1714.

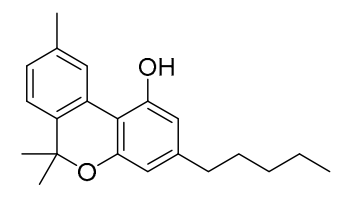

cannabinol (CBN, 4)

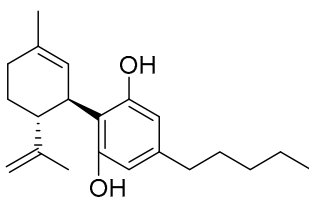

cannabidiol $(\mathrm{CBD}, 5)$

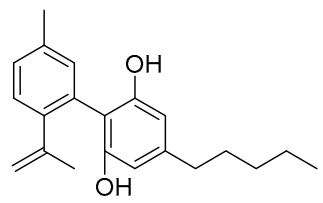

cannabinodiol (CBND, 6)

Figure 2. Chemical structures of the phytocannabinoids cannabinol (CBN), cannabidiol (CBD), and cannabinodiol (CBND).

The present work is informed by our findings with analogs of (-)- $\Delta^{8}$-tetrahydrocannabinol (THC) and (-)-hexahydrocannabinol (HHC) with cyclic moieties at the $\mathrm{C}^{\prime}$ position of the side chain pharmacophore [34-37] (Figure 1). These studies have shown that analogs with six- to eight-atoms-long side chains substituted at $\mathrm{C1}^{\prime}$ with a cyclopentyl ring exhibit remarkably high affinities for CB1 and CB2 receptors. Taken together, in this study our design replaces the $1^{\prime}, 1^{\prime}$-gem-dimethyl group in the cannabilactone scaffold with the larger and sterically more confined cyclopentyl group (Figure 1). Additionally, we have explored the pharmacophoric limits of side chain length, while the polar 
characteristics have been enhanced by incorporating bromo- and cyano-substituents at the terminal carbon atom $[37,38]$. All synthesized compounds were assessed for their binding affinities at rat CB1 (rCB1) and mouse CB2 (mCB2) receptors while the most promising analogs were also tested in human CB2 (hCB2) to identify potential species differences between the mouse and human clone. One of the analogs synthesized namely AM4346 has very high affinity $\left(K_{i}=4.9 \mathrm{nM}\right)$ and 131-fold selectivity for mCB2 over rCB1 and behaves as a potent $\mathrm{CB} 2$ agonist in the cyclase assay. The species difference in the affinities of AM4346 between the mouse and the human CB2 receptors is reduced when compared to our first-generation compound AM1714, while AM4346 is endowed with enhanced polarity due to the presence of the cyano group. Additionally, we extended our SAR to include the biphenyl synthetic intermediates 23a-23d as they encompasses the biaryl subunit which is a privileged structure (biaryls found in $4.3 \%$ of known drugs), and also, they have structural similarities with the phytocannabinoid cannabidiol and its oxidative metabolite cannabinodiol (Figure 2) [39-42].

\section{Results and Discussion}

\subsection{Chemistry}

We conjectured that cannabilactones would be assessible from biphenyl compounds 7 via lactonization (Scheme 1). The bromo- or cyano-group on the C3-side chain of cannabilactones would be introduced to either the biphenyl or the cannabilactone template via substitution. Disconnection of biphenyl compounds 7 through a Suzuki coupling led to boronic acid 8 and aryl bromides 9 .

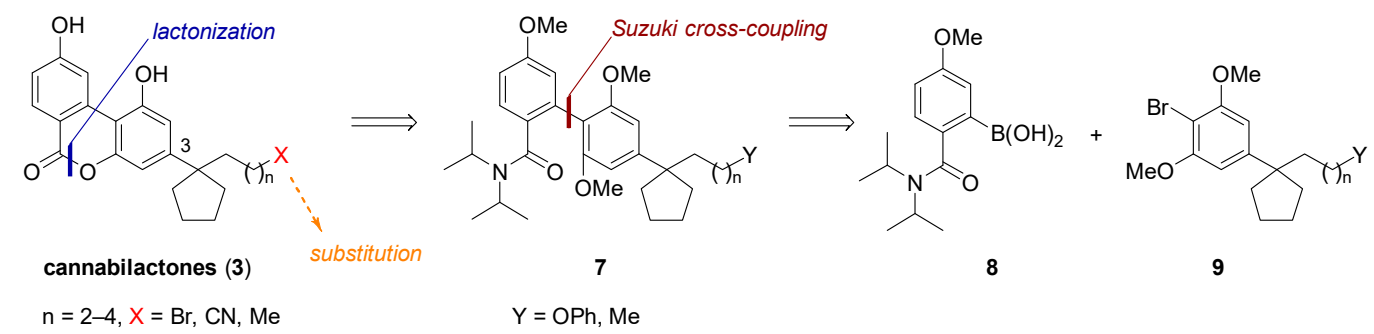

Scheme 1. Retrosynthetic analysis of cannabilactones.

The synthesis of aryl bromides $\mathbf{9 a - 9} \mathbf{d}$ is summarized in Scheme 2. Bromides $9 \mathbf{a}-\mathbf{9} \mathbf{c}$ were prepared in a general approach starting from commercially available 4-bromo-3,5-dihydroxybenzoic acid (10). Following the procedure of Luning et al. [43], etherification of the phenolic hydroxyl groups as well as, esterification of the carboxylic acid was accomplished in a single step by refluxing a mixture of 10, potassium carbonate, and dimethyl sulfate in acetone. Reduction of the resulting ester 11 with diisobutylaluminum hydride (DIBAL-H) gave benzylic alcohol 12. Although the conversion of 12 to the benzyl chloride has been reported [44], we adopted a more convenient and higher yielding approach. This involved refluxing a mixture of $\mathbf{1 2}$ and triphenylphosphine in dry carbon tetrachloride for two hours $[35,45,46]$ to give $\mathbf{1 3}$ in 93\% yield. Treatment of $\mathbf{1 3}$ with sodium cyanide in dimethyl sulfoxide afforded benzyl nitrile 14 in $87 \%$ yield $[35,44]$. Sequential deprotonation of 14 using potassium bis(trimethylsilyl)amide and cyclobisalkylation using 1,4-dibromobutane in tetrahydrofuran (THF) at $0{ }^{\circ} \mathrm{C}$ produced cyclopentyl nitrile $\mathbf{1 5}$ in $70 \%$ yield [35,47]. This was transformed to aldehyde $\mathbf{1 6}$ in $85 \%$ yield with DIBAL-H at $-78^{\circ} \mathrm{C}$ [48]. 

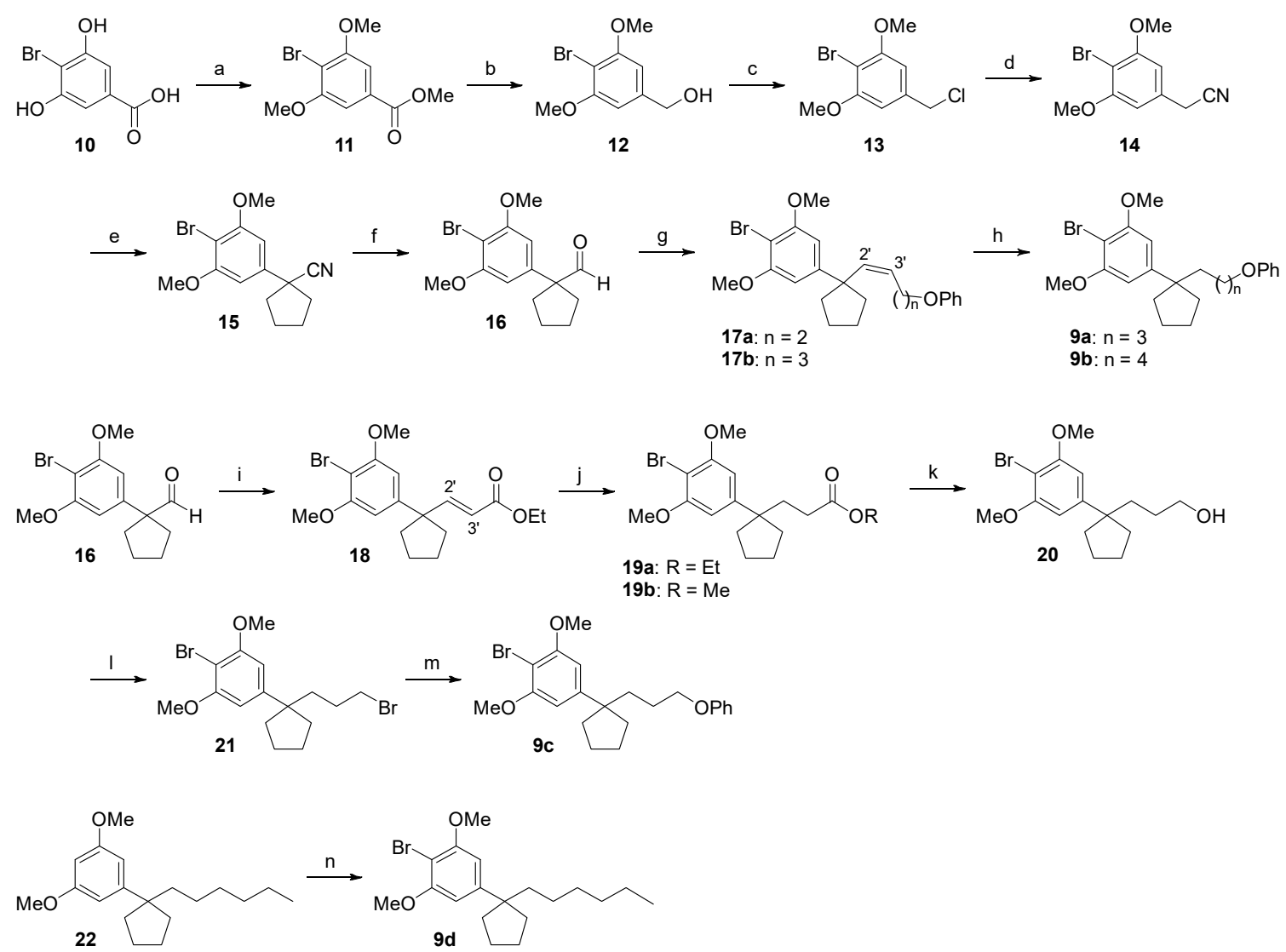

Scheme 2. Synthesis of aryl bromides ${ }^{a}$.

${ }^{a}$ Reagents and conditions: (a) $\mathrm{Me}_{2} \mathrm{SO}_{4}, \mathrm{~K}_{2} \mathrm{CO}_{3}$, acetone, reflux, 92\%; (b) DIBAL-H, THF, rt, $1 \mathrm{~h}$, 85\%; (c) $\mathrm{Ph}_{3} \mathrm{P}, \mathrm{CCl}_{4}$, reflux, 93\%; (d) NaCN, DMSO, rt, overnight, 87\%; (e) KHMDS, 1,4-dibromobutane, $\mathrm{THF}, 0{ }^{\circ} \mathrm{C}$, $5 \mathrm{~min}, 70 \%$; (f) DIBAL-H, $\mathrm{CH}_{2} \mathrm{Cl}_{2},-78{ }^{\circ} \mathrm{C}, 1 \mathrm{~h}, 85 \%$; (g) (3-phenoxypropyl)- or (4-phenoxybutyl)triphenylphosphonium bromide, KHMDS, THF, $0{ }^{\circ} \mathrm{C}, 10 \mathrm{~min}, 94 \%$ for 17 a and 93\% for 17b; (h) $\mathrm{H}_{2}, \mathrm{Pd} / \mathrm{C}, \mathrm{EtOAc}, \mathrm{rt}, 12 \mathrm{~h}, 95 \%$ for $9 \mathbf{a}$ and $94 \%$ for $\mathbf{9 b}$; (i) triethyl phosphonoacetate, $\mathrm{NaH}, \mathrm{THF}, 92 \%$; (j) for 19a: $\mathrm{H}_{2}, \mathrm{Pd} / \mathrm{C}$, EtOAc, $30 \mathrm{psi}, 95 \%$; for 19b: $\mathrm{Mg} / \mathrm{MeOH}, 0{ }^{\circ} \mathrm{C}, 2 \mathrm{~h}$, then rt, $12 \mathrm{~h}$, 80\%; (k) DIBAL-H, THF, rt, $1 \mathrm{~h}, 86 \%$ from 19a, 85\% from $19 \mathrm{~b}$; (l) $\mathrm{Ph}_{3} \mathrm{P} / \mathrm{CBr}_{4}, 0{ }^{\circ} \mathrm{C} \rightarrow \mathrm{rt}, 85 \%$; (m) $\mathrm{NaOPh}$, DMSO, rt, 20 h, 50\%; (n) $\mathrm{Br}_{2}, \mathrm{CCl}_{4}, 0{ }^{\circ} \mathrm{C}, 1 \mathrm{~h}, 78 \%$.

Wittig olefination of aldehyde 16 with (3-phenoxypropyl)- and (4-phenoxybutyl) triphenylphosphonium bromides gave exclusively cis-alkenes 17a and 17b, respectively, in 93-94\% yields. The geometry of the newly formed double bond in $\mathbf{1 7 a}$ and $\mathbf{1 7 b}$ was assigned based on the ${ }^{1} \mathrm{H}$ NMR spectra of crude products $\left({ }^{3} J_{\mathrm{H} 2^{\prime}-\mathrm{H} 3^{\prime}} \sim 11.3 \mathrm{~Hz}\right)$. Reduction of these alkenes by catalytic hydrogenation afforded the corresponding aryl bromides $\mathbf{9 a}$ and $\mathbf{9 b}$. Wittig olefination of aldehyde 16 with (2-phenoxyethyl)triphenylphosphonium bromide was not successful because vinyltriphenylphosphonium bromide was generated under the reaction conditions [49]. To prepare aryl bromide 9c, a slightly modified route was followed. Horner-Wardsworth-Emmons olefination of aldehyde 16 with commercially available triethyl phosphonoacetate [50-52] produced exclusively trans-conjugated ester 18 in 92\% yield $\left({ }^{3} \mathrm{~J}_{\mathrm{H} 2^{\prime}-\mathrm{H} 3^{\prime}} \sim 15.8 \mathrm{~Hz}\right)$. Palladium-catalyzed hydrogenation of 18 in ethyl acetate required high pressure (30 psi) to produce ethyl ester 19a in 95\% yield, whereas exposure of 18 to magnesium turnings in methanol gave methyl ester 19b in 80\% yield [53]. Reduction of either 19a or $19 b$ with DIBAL-H at room temperature gave alcohol 20 (85-86\% yield). This was followed by treatment of 20 with triphenylphosphine and carbon tetrabromide to afford 21 in $85 \%$ yield. Phenoxide displacement of $\mathbf{2 1}$ in dimethyl sulfoxide provided aryl bromide $9 \mathrm{c}$ in moderate yield (50\%). Additionally, aryl bromide $\mathbf{9 d}$ was prepared via bromination of resorcinol dimethyl ether 22 [35] using bromine in carbon tetrachloride (78\% yield) [54]. 
With aryl bromides $\mathbf{9 a - 9 d}$ in hand, we proceeded to complete the synthesis of cannabilactones (Scheme 3). Suzuki cross-coupling of aryl bromides 9a-9d with boronic acid $\mathbf{8}$, which was prepared from commercially available 4-methoxybenzoic acid $[55,56]$, furnished the sterically hindered biphenyls 7a-7d in $48-50 \%$ yields.
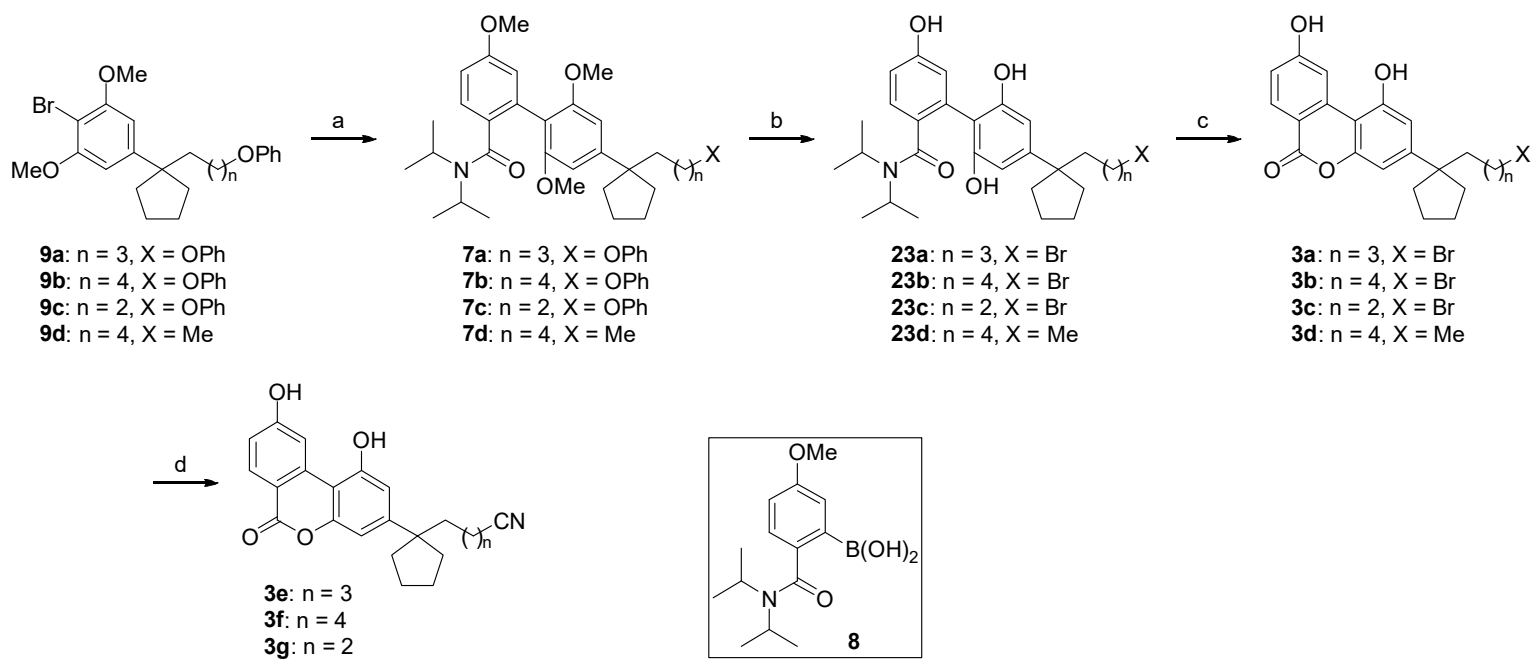

Scheme 3. Synthesis of cannabilactones ${ }^{a}$.

${ }^{a}$ Reagents and conditions: (a) 8, $\mathrm{Ba}(\mathrm{OH})_{2}, \mathrm{DME} / \mathrm{H}_{2} \mathrm{O}, \mathrm{Pd}\left(\mathrm{Ph}_{3} \mathrm{P}\right)_{4}, 80{ }^{\circ} \mathrm{C}, 6 \mathrm{~h}, 48 \%$ for $7 \mathbf{a}$ from 9a, $50 \%$ for $7 \mathbf{b}$ from $9 \mathbf{b}, 50 \%$ for $7 \mathrm{c}$ from 9 c, and $50 \%$ for $7 \mathbf{d}$ from $9 d$; (b) $\mathrm{BBr}_{3}, \mathrm{CH}_{2} \mathrm{Cl}_{2},-78{ }^{\circ} \mathrm{C}, \mathrm{rt}, 12 \mathrm{~h}$, $92 \%$ for $\mathbf{2 3 a}$ from $\mathbf{7 a}, \mathbf{9 0} \%$ for $\mathbf{2 3 b}$ from $\mathbf{7 b}, \mathbf{9 1} \%$ for $\mathbf{2 3 c}$ from $\mathbf{7 c}$, and $89 \%$ for $\mathbf{2 3 d}$ from $\mathbf{7 d}$; (c) $\mathrm{AcOH}$, reflux, 24 h, $89 \%$ for $3 \mathbf{a}$ from $\mathbf{2 3 a}, 90 \%$ for $\mathbf{3 b}$ from $\mathbf{2 3 b}, 91 \%$ for $3 \mathbf{c}$ from $\mathbf{2 3 c}$, and $91 \%$ for $\mathbf{3 d}$ from $\mathbf{2 3 d}$; (d) $\mathrm{NaCN}, \mathrm{DMSO}, \mathrm{rt}, 24 \mathrm{~h}, 72 \%$ for $3 \mathbf{e}$ from $3 \mathbf{a}, 69 \%$ for $3 \mathbf{f}$ from $3 \mathbf{b}$, and $70 \%$ for $\mathbf{3 g}$ from $3 \mathbf{c}$.

Exposure of 7a-7d to boron tribromide led to trihydroxybiphenyl intermediates 23a-23d in 89-92\% yields, in which cleavage of all methyl ether groups and of the phenolic ether with introduction of the bromide in the case of $7 \mathbf{a}-7 \mathbf{c}$ took place in a single step. Acetic acid mediated lactonization of polyphenols 23a-23d afforded cannabilactones 3a-3d in 89-91\% yields. Subsequent exposure of 3a-3c to sodium cyanide in dimethyl sulfoxide gave nitriles $\mathbf{3 e}-\mathbf{3 g}$.

\subsection{Affinity for Cannabinoid Receptors}

The abilities of the cannabilactone analogs $3 \mathbf{a}-\mathbf{3 g}$ to displace the radiolabeled CB1/CB2 agonist CP-55,940 from membranes prepared from rat brain (a source of CB1) and HEK293 cells expressing mouse CB2 were determined as described earlier $[38,57,58]$. Inhibition constant values $\left(K_{\mathrm{i}}\right)$ from the respective competition binding curves are listed in Table 1 in which our first generation cannabilactone analog AM1714 is included for comparison. The current data of AM1714 for mCB2 are slightly different when compared to those we published earlier [27]. This is because the compound was first assayed in a different $\mathrm{mCB} 2$ receptor preparation, e.g., mouse spleen membrane.

It should also be noted that the rat, mouse, and human CB1 receptors have 97-99\% sequence identity across species and, as shown earlier (see for example [12,37,38,57]), are not expected to exhibit variations in their $K_{\mathrm{i}}$ values. However, the CB2 receptor shows less homology ( 82\%) between species than does CB1 (97-99\%), and that variability could cause species-related differences in affinity. Indeed, in our original work on the cannabilactone class of compounds, we have identified species-specific variation in CB2 affinity [27]. For this reason, the key compounds were also assayed using membranes from HEK293 cells expressing human CB2 (hCB2). Data from the latter preparation are listed in Table 2.

As shown in Table 1, replacement of the $C 1^{\prime}$-gem-dimethyl group with the bulkier, more sterically confined cyclopentyl ring produces cannabilactone analogs with enhanced affinity and selectivity for 
the $\mathrm{mCB} 2$ relative to the $\mathrm{rCB} 1$ receptors. We also observe that this trend for $\mathrm{mCB} 2 \mathrm{selectivity}$ can be optimized by varying the length of the side chain and the substituent at the terminal carbon atom. Thus, analogs carrying five- to seven-atoms long side chains terminated with a bromine atom or a cyano group (3c, 3a, 3b, 3g, and 3e) exhibit 16- to 26-fold selectivity for mCB2 over rCB1. The more lipophilic C1'-gem-dimethyl-heptyl (1b) and C1'-cyclopentyl-heptyl (3d) analogs have comparable affinity $\left(K_{\mathrm{i}}=4.7 \pm 1.8 \mathrm{nM}\right.$ and $\left.8.4 \pm 2.5 \mathrm{nM}\right)$ and selectivity (21- to 32-fold) for mCB2 over rCB1. Within these series, however, analog AM4346 with its longer chain (eight atoms) and C6'-cyano substituent has optimal properties: maximal binding affinity for $\mathrm{mCB} 2$ and minimal affinity for $\mathrm{rCB} 1$. In fact, AM4346 exhibits a remarkable 131-fold selectivity for mCB2 over rCB1.

The binding affinities for the human CB2 (hCB2) receptor of the three key analogs AM1714, AM4348, and AM4346 are listed in Table 2. We observe that although all analogs exhibit somewhat reduced affinity for hCB2 as compared to $\mathrm{mCB} 2$ (Table 1), the $\mathrm{C1}^{\prime}$-cyclopentyl-analogs show a pronounced reduction in the affinity differences between $\mathrm{mCB} 2$ and hCB2 as compared to $\mathrm{C1} 1^{\prime}$-gem-dimethyl analog. Thus, AM1714 has 18-fold greater affinity for $\mathrm{mCB} 2$ than for hCB2, but this preference is reduced to 3-fold for AM4348 and 7-fold for AM4346. With a roughly 19-fold preference, analog AM4346 has the highest selectivity for hCB2 over rCB1.

Table 1. Affinities of side chain-modified cannabilactone analogs for rCB1 and mCB2 cannabinoid receptors ( $\pm 95 \%$ confidence limits).

rCB1/mCB2

${ }^{1}$ Affinities were determined using rat brain (CB1) or membranes from HEK293 cells expressing mouse CB2 and $\left[{ }^{3} \mathrm{H}\right] \mathrm{CP}-55,940$ as the radioligand following previously described procedures $[38,57,58]$. Data were analyzed using nonlinear regression analysis. $K_{\mathrm{i}}$ values were obtained from three independent experiments performed in triplicate and are expressed as the mean of the three values. 
Table 2. Affinities of key cannabilactone analogs for hCB2 cannabinoid receptors ( $\pm 95 \%$ confidence limits).

rCB1/hCB2 $\quad$ hCB2/mCB2

\footnotetext{
${ }^{1}$ Cannabinoid receptors were prepared as described for Table 1, except that hCB2 was from HEK293 expressing the human and not the mouse protein. Binding affinities were determined, and data were analyzed as for Table 1. Affinities for rCB1 (from Table 1) are included for comparison.
}

Synthesized as precursors to cannabilactones, binding affinities of the intermediate biphenyl compounds 23a-23d for rCB1 and mCB2 were also determined (Table 3). To our surprise, these biphenyl analogs bind $\mathrm{mCB} 2$ with high affinity and substantial selectivity for that receptor over rCB1. In this series, the $\mathrm{C}^{\prime}$-cyclopentyl-heptyl analog AM4347 has both the greatest binding affinity $\left(K_{\mathrm{i}}=5.7\right.$ $\pm 1.5 \mathrm{nM}$ ) for $\mathrm{mCB} 2$ and the highest selectivity (60-fold) for that receptor over rCB1.

Table 3. Affinities of biphenyl analogs for $\mathrm{rCB} 1$ and $\mathrm{mCB} 2$ cannabinoid receptors ( $\pm 95 \%$ confidence limits).

Compound

\footnotetext{
${ }^{1}$ Cannabinoid receptors were prepared, binding affinities measured, and data analyzed as described for Table 1.
} 


\subsection{Functional Characterization}

Functional characterization of three key cannabilactones (AM1710, AM1714, and AM4346) for the hCB2 receptor was carried out by measuring the decrease in forskolin stimulated cAMP, as detailed earlier $[38,57]$. Data are listed in Table 4 in which the standard cannabinoid agonist CP-55,940 is included for comparison. Our testing results show that all three compounds potently decreased the levels of cAMP, indicating that within this signaling mechanism these compounds behaved as potent agonists at the $\mathrm{hCB} 2$ receptor with the $\mathrm{C} 1^{\prime}$-cyclopentyl-analog AM4346 being more potent $\left(\mathrm{EC}_{50}=3.7 \pm\right.$ $\left.1.5 \mathrm{nM}, E_{(\max )}=89 \%\right)$ than the C1'-gem-dimethyl-analogs AM1710 and AM1714 $\left(\mathrm{EC}_{50}=10.5 \pm 2.5 \mathrm{nM}\right.$, $E_{(\max )}=73 \%$ and $\mathrm{EC}_{50}=36.9 \pm 6.8 \mathrm{nM}, E_{(\max )}=77 \%$ respectively).

In the same assay, one of the biphenyl analogs, compound 23d (AM4347), failed to show any responses in concentrations up to $2 \mu \mathrm{M}$.

Table 4. Functional potencies $\left(\mathrm{EC}_{50}\right)$ of key cannabilactones and $\mathrm{CP}-55,940$ for the hCB2 cannabinoid receptor $( \pm 95 \%$ confidence limits).

\begin{tabular}{ccc}
\hline \multirow{2}{*}{ Compound } & $E C_{\mathbf{5 0}}(\mathbf{n M})^{\mathbf{1}}$ (classification) & $E(\max )(\mathbf{\%})^{\mathbf{2}}$ \\
\cline { 2 - 3 } hCB2 & \\
\hline CP-55,940 & $3.4 \pm 1.2$ (agonist) & 100 \\
$\mathbf{1 a}$ & $10.5 \pm 2.5$ (agonist) & 73 \\
AM1710 & $36.9 \pm 6.8$ (agonist) & 77 \\
$\mathbf{~ 1 b}$ & $3.7 \pm 1.5$ (agonist) & 89 \\
AM1714 &
\end{tabular}

\footnotetext{
${ }^{1}$ Functional potencies at hCB2 receptor were determined by measuring the decrease in forskolin-stimulated cAMP levels $[38,57] . \mathrm{EC}_{50}$ values were calculated using nonlinear regression analysis. Data are the average of two independent experiments run in triplicate. ${ }^{2}$ Forskolin stimulated cAMP levels were normalized to $100 \%$. $\mathrm{E}(\max )$ is the maximum inhibition of forskolin stimulated cAMP levels and is presented as the percentage of CP-55,940 response at $500 \mathrm{nM}$.
}

\section{Experimental Section}

Materials: all reagents and solvents were purchased from Aldrich Chemical Company, unless otherwise specified, and used without further purification. All anhydrous reactions were performed under a static argon atmosphere in flame-dried glassware using scrupulously dry solvents. Flash column chromatography employed silica gel 60 (230-400 mesh). All compounds were demonstrated to be homogeneous by analytical TLC on pre-coated silica gel TLC plates (Merck, $60 \mathrm{~F}_{245}$ on glass, layer thickness $250 \mu \mathrm{m}$ ), and chromatograms were visualized by phosphomolybdic acid staining. Melting points were determined on a micro-melting point apparatus and are uncorrected. IR spectra were recorded on a Perkin Elmer Spectrum One FT-IR spectrometer. NMR spectra were recorded in $\mathrm{CDCl}_{3}$, unless otherwise stated, on a Bruker Ultra Shield $400 \mathrm{WB}$ plus $\left({ }^{1} \mathrm{H}\right.$ at $400 \mathrm{MHz},{ }^{13} \mathrm{C}$ at $\left.100 \mathrm{MHz}\right)$ or on a Varian INOVA-500 $\left({ }^{1} \mathrm{H}\right.$ at $\left.500 \mathrm{MHz}\right)$ spectrometers and chemical shifts are reported in units of $\delta$ relative to internal TMS. Multiplicities are indicated as br (broadened), s (singlet), d (doublet), $\mathrm{t}$ (triplet), $\mathrm{q}$ (quartet), $\mathrm{m}$ (multiplet) and coupling constants $(J)$ are reported in hertz (Hz). Low and high-resolution mass spectra were performed in School of Chemical Sciences, University of Illinois at Urbana-Champaign. Mass spectral data are reported in the form of $\mathrm{m} / \mathrm{z}$ (intensity relative to base $=100$ ).

4-Bromo-3,5-dimethoxybenzyl chloride (13). To a stirred solution of 4-bromo-3,5-dimethoxyphenylmethanol (12) $(4.74 \mathrm{~g}, 19.2 \mathrm{mmol})$ in anhydrous carbon tetrachloride $(200 \mathrm{~mL})$ at room temperature under an argon atmosphere was added triphenylphosphine (11.6 g, $42.2 \mathrm{mmol}$ ). The reaction mixture was refluxed for $45 \mathrm{~min}$ and then cooled to room temperature with spontaneous precipitation of triphenylphosphine oxide. To this suspension was added anhydrous hexane, the white precipitate was filtered off, washed with hexane, and the combined filtrate was evaporated under reduced pressure. The residue purified by flash column chromatography on silica 
gel (20\% diethyl ether in petroleum ether) to give compound $\mathbf{1 3}(4.74 \mathrm{~g}, 93 \%$ yield) as a colorless oil which crystallized on standing. mp $65-67^{\circ} \mathrm{C}$ (lit [44]. mp $\left.69{ }^{\circ} \mathrm{C}\right) ;{ }^{1} \mathrm{H} \mathrm{NMR}\left(500 \mathrm{MHz}, \mathrm{CDCl}_{3}\right) \delta 6.60(\mathrm{~s}$, 2H, 2-H, 6-H), 4.55 (s, 2H, - $\mathrm{CH}_{2} \mathrm{Cl}$ ), 3.92 (s, 6H, OMe). The 4-bromo-3,5-dimethoxyphenylmethanol (12) was synthesized in two steps from commercially available 4-bromo-3,5-dihydroxybenzoic acid (10), following previously reported procedures [43].

4-Bromo-3,5-dimethoxyphenylacetonitrile (14). To a stirred suspension of sodium cyanide (2.9 g, $40.8 \mathrm{mmol})$ in DMSO $(80 \mathrm{~mL})$ at room temperature was added a solution of $\mathbf{1 3}(4.3 \mathrm{~g}, 16.2 \mathrm{mmol})$ in DMSO $(80 \mathrm{~mL})$ over a period of $10 \mathrm{~min}$. The reaction mixture was stirred vigorously overnight and then diluted by adding ice, saturated aqueous $\mathrm{NaCl}$ solution and diethyl ether. The organic layer was separated, and the aqueous phase was extracted with diethyl ether. The combined organic layer was washed with brine, dried over $\mathrm{MgSO}_{4}$ and the solvent was evaporated under reduced pressure. The residue purified by flash column chromatography on silica gel (50\% diethyl ether in petroleum ether) to give 14 in $87 \%$ yield (3.6 g). mp $123-125^{\circ} \mathrm{C}$ (lit [44]. mp 125-126 $\left.{ }^{\circ} \mathrm{C}\right) ;{ }^{1} \mathrm{H} \mathrm{NMR}(500 \mathrm{MHz}$, $\left.\mathrm{CDCl}_{3}\right) \delta 6.52$ (s, 2H, 2-H, 6-H), 3.92 (s, 6H, OMe), 3.74 (s, 2H, $\left.-\mathrm{CH}_{2} \mathrm{CN}\right)$.

1-(4-Bromo-3,5-dimethoxyphenyl)cyclopentanecarbonitrile (15). To a solution of 14 (3.42 g, $13.36 \mathrm{mmol})$ in anhydrous THF $(120 \mathrm{~mL})$, at $0{ }^{\circ} \mathrm{C}$ under an argon atmosphere, was added potassium bis(trimethylsilyl)amide $(8 \mathrm{~g}, 40.2 \mathrm{mmol})$. The resulting slurry was stirred at the same temperature for $10 \mathrm{~min}$, and then a solution of 1,4-dibromobutane (3.46 g, $16 \mathrm{mmol})$ in anhydrous THF (20 mL) was added dropwise. The reaction was stirred for an additional $10 \mathrm{~min}$ at $0{ }^{\circ} \mathrm{C}$ and then quenched by adding saturated aqueous $\mathrm{NH}_{4} \mathrm{Cl}$ solution $(80 \mathrm{~mL})$. The mixture was warmed to room temperature and diluted with diethyl ether $(200 \mathrm{~mL})$. The organic layer was separated and the aqueous phase extracted with diethyl ether. The combined organic layer was washed with brine and dried over $\mathrm{MgSO}_{4}$ and the solvent evaporated under reduced pressure. The residue was purified by flash column chromatography on silica gel (25\% diethyl ether in hexane) to give $\mathbf{1 5}$ as a white solid in $70 \%$ yield (2.9 g). mp 135-138 ${ }^{\circ} \mathrm{C} ;{ }^{1} \mathrm{H}$ NMR (500 MHz, CDCl $) \delta 6.65$ (s, 2H, 2-H, 6-H), 3.92 (s, 6H, OMe), 2.54-2.45 $(\mathrm{m}, 2 \mathrm{H}$ of the cyclopentane ring), $2.14-2.04(\mathrm{~m}, 4 \mathrm{H}$ of the cyclopentane ring), 2.02-1.94 ( $\mathrm{m}, 2 \mathrm{H}$ of the cyclopentane ring); mass spectrum $m / z$ (relative intensity) $311\left(\mathrm{M}^{+}+2,99\right), 309\left(\mathrm{M}^{+}, 100\right), 270(80), 268$ (81), 257 (6), 255 (6), 245 (7), 243, (7), 218 (10), 216 (10), exact mass calculated for $\mathrm{C}_{14} \mathrm{H}_{16} \mathrm{BrNO}_{2} 309.0364$, found 309.0362 .

1-(4-Bromo-3,5-dimethoxyphenyl)cyclopentanecarboxaldehyde (16). To a stirred solution of $15(1.40 \mathrm{~g}, 4.52 \mathrm{mmol})$ in dry $\mathrm{CH}_{2} \mathrm{Cl}_{2}(50 \mathrm{~mL})$, at $-78^{\circ} \mathrm{C}$, under an argon atmosphere, was added diisobutylaluminum hydride (1 M solution in hexanes, $12 \mathrm{~mL})$ dropwise. The reaction mixture was stirred at the same temperature for $1 \mathrm{~h}$, and then quenched by the dropwise addition of potassium sodium tartrate (10\% solution in water). The mixture was warmed to room temperature and stirred vigorously for $1 \mathrm{~h}$. The organic layer was separated, and the aqueous phase extracted with diethyl ether. The combined organic layer was washed with brine, dried over $\mathrm{MgSO}_{4}$ and concentrated in vacuo. The crude product was purified by flash column chromatography on silica gel (25\% diethyl ether in hexane) to give 16 as a white solid in $85 \%$ yield $(1.2 \mathrm{~g}) . \operatorname{mp} 88-91{ }^{\circ} \mathrm{C} ;{ }^{1} \mathrm{H} \mathrm{NMR}\left(400 \mathrm{MHz}, \mathrm{CDCl}_{3}\right) \delta$ 9.39 (s, 1H, CHO), 6.44 (s, 2H, 2-H, 6-H), 3.90 (s, 6H, OMe), 2.56-2.47 (m, 2H of the cyclopentane ring), $1.95-1.86(\mathrm{~m}, 2 \mathrm{H}$ of the cyclopentane ring), 1.84-1.73 (m, 2H of the cyclopentane ring), 1.72-1.62 (m, 2H of the cyclopentane ring); mass spectrum $\mathrm{m} / \mathrm{z}$ (relative intensity), $314(\mathrm{M}++2,20), 312(\mathrm{M}+, 21), 285$ (100), 283 (100), 270 (6), 268 (6); exact mass calculated for $\mathrm{C}_{14} \mathrm{H}_{17} \mathrm{BrO}_{3}$ 312.0361, found 312.0361.

2-Bromo-1,3-dimethoxy-5-[1-(1,2-cis-4-phenoxy-buten-1-yl)cyclopentyl]benzene (17a). To a stirred suspension of 3-(phenoxypropyl)triphenylphosphonium bromide (2.30 g $4.82 \mathrm{mmol})$ in dry THF $(50 \mathrm{~mL})$ at $0{ }^{\circ} \mathrm{C}$, under an argon atmosphere was added potassium bis(trimethylsilyl)amide $(0.94 \mathrm{~g}$, $4.72 \mathrm{mmol})$. To the resulting slurry was added a solution of $\mathbf{1 6}(0.30 \mathrm{~g}, 0.96 \mathrm{mmol})$ in dry THF (5 mL) dropwise. Stirring was continued for an additional $10 \mathrm{~min}$ at the same temperature and the reaction was quenched by adding saturated aqueous $\mathrm{NH}_{4} \mathrm{Cl}(20 \mathrm{~mL})$. The mixture was warmed to room temperature and diluted with diethyl ether $(40 \mathrm{~mL})$. The organic layer was separated and the aqueous phase extracted with diethyl ether. The combined organic layer was washed with brine, dried over $\mathrm{MgSO}_{4}$ 
and the solvent evaporated under reduced pressure. The residue was chromatographed through a column of silica gel (10\% diethyl ether in petroleum ether) to give 17a as a colorless liquid in $94 \%$ yield (390 mg); ${ }^{1} \mathrm{H}$ NMR (400 MHz, CDCl $) \delta 7.23$ (t, $\left.J=8.1 \mathrm{~Hz}, 2 \mathrm{H}, 3-\mathrm{H}, 5-\mathrm{H}, \mathrm{OPh}\right), 6.91(\mathrm{t}, J=8.1 \mathrm{~Hz}, 1 \mathrm{H}$, 4-H, OPh), 6.75 (d, J = 8.1 Hz, 2H, 2-H, 6-H, OPh), 6.61 (s, 2H, ArH), 5.90 (d, J = 11.3 Hz, 1H, 2'-H), 5.46 $\left.\left(\mathrm{dt}, J=11.3 \mathrm{~Hz}, J=7.3 \mathrm{~Hz}, 1 \mathrm{H}, 3^{\prime}-\mathrm{H}\right), 3.86(\mathrm{~s}, 6 \mathrm{H}, \mathrm{OMe}), 3.74\left(\mathrm{t}, \mathrm{J}=6.6 \mathrm{~Hz}, 2 \mathrm{H}, 5^{\prime}-\mathrm{H}\right)\right), 2.20(\mathrm{q}, J=6.8 \mathrm{~Hz}$, $\left.2 \mathrm{H}, 4^{\prime}-\mathrm{H}\right), 2.19-1.93(\mathrm{~m}, 4 \mathrm{H}$ of the cyclopentane ring), $1.85-1.70(\mathrm{~m}, 4 \mathrm{H}$ of the cyclopentane ring); mass spectrum $m / z$ (relative intensity) $432\left(\mathrm{M}^{+}+2,68\right), 430\left(\mathrm{M}^{+}, 67\right), 338$ (62), 309 (35), 258 (65), 231 (90), 229 (90), 176 (52), 121 (100), 90 (78), 77 (72); exact mass calculated for $\mathrm{C}_{23} \mathrm{H}_{27} \mathrm{BrO}_{3}$ 430.1144, found 430.1146.

2-Bromo-1,3-dimethoxy-5-[1-(1,2-cis-5-phenoxy-penten-1-yl)cyclopentyl]benzene

The synthesis was carried our as described for 17a using (4-phenoxybutyl)triphenylphosphonium bromide $(3.18 \mathrm{~g}, 6.47 \mathrm{mmol})$ in anhydrous THF $(40 \mathrm{~mL})$, potassium bis(trimethylsilyl)amide $(1.72 \mathrm{~g}$, $6.36 \mathrm{mmol})$, and a solution of $16(0.42 \mathrm{~g}, 1.35 \mathrm{mmol})$ in anhydrous THF $(5 \mathrm{~mL})$. The crude product obtained after work up was chromatographed through a column of silica gel (10\% diethyl ether in petroleum ether) to give $\mathbf{1 7 b}$ as a colorless liquid in $93 \%$ yield $(0.56 \mathrm{~g}) .{ }^{1} \mathrm{H} \mathrm{NMR}\left(400 \mathrm{MHz}, \mathrm{CDCl}_{3}\right) \delta$ $7.26(\mathrm{t}, J=8.0 \mathrm{~Hz}, 2 \mathrm{H}, 3-\mathrm{H}, 5-\mathrm{H}, \mathrm{OPh}), 6.91(\mathrm{t}, J=8.0 \mathrm{~Hz}, 1 \mathrm{H}, 4-\mathrm{H}, \mathrm{OPh}), 6.79$ (d, J = 8.0 Hz, 2H, 2-H, 6-H, OPh), 6.60 (s, 2H, ArH), 5.79 (d, J = 11.3 Hz, 1H, 2' -H), 5.37 (dt, J=11.3 Hz, J = 7.3 Hz, 1H, 3'-H), $3.86(\mathrm{~s}, 6 \mathrm{H}, \mathrm{OMe}), 3.70\left(\mathrm{t}, \mathrm{J}=6.5 \mathrm{~Hz}, 2 \mathrm{H}, 6^{\prime}-\mathrm{H}\right), 2.05-1.87\left(\mathrm{~m}, 6 \mathrm{H}, 4 \mathrm{H}\right.$ of the cyclopentane ring and $4^{\prime}-\mathrm{H}^{\prime}$ overlapping), $1.80-1.78\left(\mathrm{~m}, 4 \mathrm{H}\right.$ of the cyclopentane ring), $1.63\left(\mathrm{qt}, \mathrm{J}=6.9 \mathrm{~Hz}, 2 \mathrm{H}, 5^{\prime}-\mathrm{H}\right)$; mass spectrum $m / z$ (relative intensity) $446\left(\mathrm{M}^{+}+2,9\right), 444\left(\mathrm{M}^{+}, 9\right), 348(12), 314(21), 312(21), 285(99), 283(100), 252$ (12), 231 (25), 229 (25), 204 (44), 176 (27), 133 (8), 94 (48), 67 (49); exact mass calculated for $\mathrm{C}_{24} \mathrm{H}_{29} \mathrm{BrO}_{3}$ 444.1300 , found 444.1301 .

2-Bromo-1,3-dimethoxy-5-[1-(4-phenoxybutyl)cyclopentyl]benzene (9a). A mixture of 17a (360 mg, $0.84 \mathrm{mmol})$ and $10 \% \mathrm{Pd} / \mathrm{C}(54 \mathrm{mg})$ in ethyl acetate $(20 \mathrm{~mL})$ was stirred vigorously under hydrogen atmosphere (room temperature overnight). The catalyst was removed by filtration through celite and the filtrate was evaporated under reduced pressure to give the product 9a as a viscous liquid (346 mg, $95 \%$ yield) which was used in the next step without further purification. ${ }^{1} \mathrm{H} \mathrm{NMR}\left(400 \mathrm{MHz}, \mathrm{CDCl}_{3}\right) \delta$ $7.26(\mathrm{t}, J=8.1 \mathrm{~Hz}, 2 \mathrm{H}, 3-\mathrm{H}, 5-\mathrm{H}, \mathrm{OPh}), 6.91(\mathrm{t}, J=8.1 \mathrm{~Hz}, 1 \mathrm{H}, 4-\mathrm{H}, \mathrm{OPh}), 6.83(\mathrm{~d}, J=8.1 \mathrm{~Hz}, 2 \mathrm{H}, 2-\mathrm{H}$, 6-H, OPh), 6.49 (s, 2H, ArH), 3.87 (s, 6H, OMe), 3.85 (t, J = 6.4 Hz, 2H, 5'-H), 1.95-1.88 (m, $2 \mathrm{H}$ of the cyclopentane ring), $1.87-1.79$ (m, $2 \mathrm{H}$ of the cyclopentane ring), $1.77-1.59(\mathrm{~m}, 8 \mathrm{H}, 4 \mathrm{H}$ of the cyclopentane ring and $4 \mathrm{H}$ of the 4-phenoxybutyl group), 1.22-1.14 (m, $2 \mathrm{H}$ of the 4-phenoxybutyl group); mass spectrum $m / z$ (relative intensity) $434\left(\mathrm{M}^{+}+2,24\right), 432\left(\mathrm{M}^{+}, 24\right), 342$ (16), 340 (16), 285 (100), 283 (97), 231 (24), 229 (24), 204 (32), 176 (18), 149 (19), 91 (21), 67 (34); exact mass calculated for $\mathrm{C}_{23} \mathrm{H}_{29} \mathrm{BrO}_{3} 432.1300$, found 432.1303 .

2-Bromo-1,3-dimethoxy-5-[1-(5-phenoxypentlyl)cyclopentyl]benzene (9b). The title compound was synthesized as described for 9a, using $\mathbf{1 7 b}(550 \mathrm{mg}, 1.26 \mathrm{mmol})$ and $10 \% \mathrm{Pd} / \mathrm{C}(80 \mathrm{mg}) \mathrm{in} \mathrm{EtOAc}$ $(20 \mathrm{~mL})$ and gave $9 \mathbf{b}$ as a white solid in $94 \%$ yield $(529 \mathrm{mg}) . \mathrm{mp} 65-67^{\circ} \mathrm{C} ;{ }^{1} \mathrm{H} \mathrm{NMR}\left(500 \mathrm{MHz}, \mathrm{CDCl}_{3}\right)$ $\delta 7.26(\mathrm{t}, J=8.0 \mathrm{~Hz}, 2 \mathrm{H}, 3-\mathrm{H}, 5-\mathrm{H}, \mathrm{OPh}), 6.92(\mathrm{t}, J=8.0 \mathrm{~Hz}, 1 \mathrm{H}, 4-\mathrm{H}, \mathrm{OPh}), 6.84(\mathrm{~d}, J=8.0 \mathrm{~Hz}, 2 \mathrm{H}$, 2-H, 6-H, OPh), 6.49 (s, 2H, ArH), 3.88 (s, 6H, OMe), 3.86 (t, J = 6.5 Hz, 2H, 6'-H), 1.94-1.86 (m, 2H of the cyclopentane ring), $1.85-1.77(\mathrm{~m}, 2 \mathrm{H}$ of the cyclopentane ring), $1.75-1.63(\mathrm{~m}, 6 \mathrm{H}, 4 \mathrm{H}$ of the cyclopentane ring and $2 \mathrm{H}$ of the 5-phenoxypentyl group, overlapping), 1.62-1.56 (m, 2H, 2' $-\mathrm{H}), 1.34$ (qt, $J=7.6 \mathrm{~Hz}, 2 \mathrm{H}$ of the 5-phenoxypentyl group), 1.10-1.00 (m, 2H of the 5-phenoxypentyl group); mass spectrum $m / z$ (relative intensity) $448(\mathrm{M}++2,7), 446(\mathrm{M}+, 8), 381$ (5), 331 (6), 279 (12), 231 (14), 149 (55), 119 (34), 69 (100); exact mass calculated for $\mathrm{C}_{24} \mathrm{H}_{31} \mathrm{BrO}_{3} 446.1457$, found 446.1457.

trans-3-[1-(4-Bromo-3,5-dimethoxyphenyl)cyclopentyl]acrylic acid ethyl ester (18). To a solution of triethyl phosphonoacetate $(2.78 \mathrm{~g}, 12.42 \mathrm{mmol})$ in dry $\mathrm{THF}(50 \mathrm{~mL})$, at $0{ }^{\circ} \mathrm{C}$, under an argon atmosphere, was added sodium hydride (497 $\mathrm{mg}, 12.42 \mathrm{mmol}, 60 \%$ dispersion in mineral oil). The mixture was stirred for $15 \mathrm{~min}$ at the same temperature and a solution of 16 (1.11 g, $3.55 \mathrm{mmol})$ in dry THF (10 mL) was added dropwise. Stirring was continued for an additional $10 \mathrm{~min}$, and the reaction was quenched by adding saturated aqueous $\mathrm{NH}_{4} \mathrm{Cl}(20 \mathrm{~mL})$. The mixture was warmed to room temperature and diluted with diethyl ether $(100 \mathrm{~mL})$. The organic phase was separated and the aqueous phase extracted 
with diethyl ether. The combined organic layer was washed with brine, dried over $\mathrm{MgSO}_{4}$ and evaporated under reduced pressure. The crude product was purified by flash column chromatography on silica gel ( $35 \%$ diethyl ether in hexane) to give $\mathbf{1 8}$ as a white solid in $92 \%$ yield $(1.25 \mathrm{~g})$. mp 68-72 ${ }^{\circ} \mathrm{C} ;{ }^{1} \mathrm{H}$ NMR $\left(400 \mathrm{MHz}, \mathrm{CDCl}_{3}\right) \delta 7.04(\mathrm{~d}, J=15.8 \mathrm{~Hz}, 1 \mathrm{H},>\mathrm{CH}=\mathrm{CH}<), 6.48(\mathrm{~s}, 2 \mathrm{H}, \mathrm{ArH}), 5.62(\mathrm{~d}$, $J=15.8 \mathrm{~Hz}, 1 \mathrm{H},>\mathrm{CH}=\mathrm{CH}<), 4.16\left(\mathrm{q}, J=7.1 \mathrm{~Hz}, 2 \mathrm{H}, \mathrm{OCH}_{2} \mathrm{CH}_{3}\right), 3.88(\mathrm{~s}, 6 \mathrm{H}, \mathrm{OMe}), 2.18-2.08(\mathrm{~m}, 2 \mathrm{H}$ of the cyclopentane ring), $2.07-1.96(\mathrm{~m}, 2 \mathrm{H}$ of the cyclopentane ring), $1.84-1.72(\mathrm{~m}, 4 \mathrm{H}$ of the cyclopentane ring), $1.27\left(\mathrm{t}, J=7.1 \mathrm{~Hz}, 3 \mathrm{H}, \mathrm{OCH}_{2} \mathrm{CH}_{3}\right)$; mass spectrum $\mathrm{m} / \mathrm{z}$ (relative intensity) $384\left(\mathrm{M}^{+}+2,100\right), 382$ $\left(\mathrm{M}^{+}, 100\right), 353$ (16), 339 (22), 337 (22); exact mass calculated for $\mathrm{C}_{18} \mathrm{H}_{23} \mathrm{BrO}_{4}$ 382.0780, found 382.0778.

3-[1-(4-Bromo-3,5-dimethoxyphenyl)cyclopentyl]propionic acid ethyl ester (19a). A mixture of 18 $(0.5 \mathrm{~g}, 1.3 \mathrm{mmol})$ and $10 \% \mathrm{Pd} / \mathrm{C}(100 \mathrm{mg})$ in ethyl acetate $(20 \mathrm{~mL})$ was placed in a Parr apparatus (Parr Instrument $\mathrm{Co}$, Moline, IL) and treated with hydrogen at 30 psi for $6 \mathrm{~h}$. The catalyst was removed by filtration through a pad of celite and the filtrate was evaporated under reduced pressure to give 19a as a white solid ( $472 \mathrm{mg}, 95 \%$ yield) which was used in the next step without further purification. $\mathrm{mp} 78-80{ }^{\circ} \mathrm{C} ;{ }^{1} \mathrm{H}$ NMR $\left(500 \mathrm{MHz}, \mathrm{CDCl}_{3}\right) \delta 6.48(\mathrm{~s}, 2 \mathrm{H}, \mathrm{ArH}), 4.03\left(\mathrm{q}, J=7.1 \mathrm{~Hz}, 2 \mathrm{H}, \mathrm{OCH}_{2} \mathrm{CH}_{3}\right)$, $3.89(\mathrm{~s}, 6 \mathrm{H}, \mathrm{OMe}), 2.04-1.98\left(\mathrm{~m}, 2 \mathrm{H}, 3^{\prime}-\mathrm{H}\right), 1.96-1.89\left(\mathrm{~m}, 4 \mathrm{H}, 2 \mathrm{H}\right.$ of the cyclopentane ring and $2^{\prime}-\mathrm{H}$, overlapping), $1.86-1.65\left(\mathrm{~m}, 6 \mathrm{H}\right.$ of the cyclopentane ring), $1.20\left(\mathrm{t}, J=7.1 \mathrm{~Hz}, 3 \mathrm{H}, \mathrm{OCH}_{2} \mathrm{CH}_{3}\right)$; mass spectrum $m / z$ (relative intensity), $386\left(\mathrm{M}^{+}+2,16\right), 384\left(\mathrm{M}^{+}, 15\right), 341(8), 339(8), 285(37), 283$ (36), 231 (8), 229 (8), 204 (15), 176 (9), 115 (7), 101 (9), 77 (20), 67 (100); exact mass calculated for $\mathrm{C}_{18} \mathrm{H}_{25} \mathrm{BrO}_{4}$ 384.0936, found 384.0934 .

3-[1-(4-Bromo-3,5-dimethoxyphenyl)cyclopentyl]propionic acid methyl ester (19b). A mixture of $18(0.7 \mathrm{~g}, 1.83 \mathrm{mmol})$ and magnesium turnings $(132 \mathrm{mg}, 5.5 \mathrm{mmol})$, in dry methanol $(20 \mathrm{~mL})$ was stirred at $0{ }^{\circ} \mathrm{C}$ for $2 \mathrm{~h}$ and at room temperature for an additional $12 \mathrm{~h}$. The solvent was evaporated under reduced pressure and the residue diluted with water $(20 \mathrm{~mL})$ and diethyl ether $(50 \mathrm{~mL})$. To this mixture was added $5 \%$ aqueous $\mathrm{HCl}(10 \mathrm{~mL})$, the organic layer was separated, and the aqueous layer extracted with diethyl ether. The combined ethereal layer was successively washed with $\mathrm{NaHCO}_{3}$ and brine, dried over $\mathrm{MgSO}_{4}$ and evaporated under reduced pressure to give the product $19 \mathrm{~b}$ as a white solid (543 mg, 80\% yield) which was used in the next step without further purification. $\mathrm{mp} 71-74{ }^{\circ} \mathrm{C}$; ${ }^{1} \mathrm{H}$ NMR $\left(500 \mathrm{MHz}, \mathrm{CDCl}_{3}\right) \delta 6.49$ (s, 2H, ArH), 3.91 (s, 6H, OMe), 3.60 (s, 3H, $\left.\mathrm{COOCH}_{3}\right), 2.09-2.02$ $\left(\mathrm{m}, 2 \mathrm{H}, 3^{\prime}-\mathrm{H}\right), 1.99-1.90\left(\mathrm{~m}, 4 \mathrm{H}, 2 \mathrm{H}\right.$ of the cyclopentane ring and $2^{\prime}-\mathrm{H}$, overlapping), $1.88-1.65(\mathrm{~m}, 6 \mathrm{H}$, of the cyclopentane ring); mass spectrum $m / z$ (relative intensity) $372\left(\mathrm{M}^{+}+2,98\right), 370\left(\mathrm{M}^{+}, 100\right), 341$ (19), 339 (20); exact mass calculated for $\mathrm{C}_{17} \mathrm{H}_{23} \mathrm{BrO}_{4} 370.0780$, found 370.0783.

3-[1-(4-Bromo-3,5-dimethoxyphenyl)cyclopentyl]propan-1-ol (20). To a stirred solution of $\mathbf{1 9 b}$ (520 mg, $1.4 \mathrm{mmol})$ in dry THF $(20 \mathrm{~mL})$, at room temperature, under an argon atmosphere, was added diisobutylaluminum hydride ( $3.7 \mathrm{~mL}, 1 \mathrm{M}$ solution in hexanes) over a period of $15 \mathrm{~min}$. The mixture was stirred at the same temperature for $1 \mathrm{~h}$, and then cooled to $0{ }^{\circ} \mathrm{C}$, and the reaction was quenched by dropwise addition of aqueous potassium sodium tartrate $(10 \%$ solution in water, $10 \mathrm{~mL})$. The resulting mixture was warmed to room temperature, diluted with ethyl acetate $(10 \mathrm{~mL})$ and stirred vigorously for $1 \mathrm{~h}$. The organic layer was separated, and the aqueous phase extracted with ethyl acetate. The combined organic layer was washed with brine, dried over $\mathrm{MgSO}_{4}$ and concentrated in vacuo. The residue was purified by flash column chromatography on silica gel (40\% ethyl acetate in hexane) to give 20 as a colorless liquid in $85 \%$ yield $(408 \mathrm{mg}) .{ }^{1} \mathrm{H}$ NMR $\left(500 \mathrm{MHz}, \mathrm{CDCl}_{3}\right) \delta 6.51(\mathrm{~s}, 2 \mathrm{H}, \mathrm{ArH}), 3.91(\mathrm{~s}, 6 \mathrm{H}$, $\mathrm{OMe}), 3.53\left(\mathrm{t}, J=6.4 \mathrm{~Hz}, 2 \mathrm{H}, 4^{\prime}-\mathrm{H}\right), 1.98-1.91$ (m, $2 \mathrm{H}$ of the cyclopentane ring), $1.89-1.83(\mathrm{~m}, 2 \mathrm{H}$ of the cyclopentane ring), $1.81-1.63\left(\mathrm{~m}, 6 \mathrm{H}, 4 \mathrm{H}\right.$ of the cyclopentane ring and $2^{\prime}-\mathrm{H}$, overlapping, especially $\left.1.66, \mathrm{~m}, 2^{\prime}-\mathrm{H}\right), 1.34-1.26\left(\mathrm{~m}, 2 \mathrm{H}, 3^{\prime}-\mathrm{H}\right)$; mass spectrum $\mathrm{m} / \mathrm{z}$ (relative intensity) $342\left(\mathrm{M}^{+}, 100\right), 297(26)$, 285 (10), 283 (10); exact mass calculated for $\mathrm{C}_{16} \mathrm{H}_{23} \mathrm{BrO}_{3} 342.0831$, found 342.0829. This compound was also synthesized by using 19a ( $462 \mathrm{mg}, 1.2 \mathrm{mmol})$ in anhydrous THF $(10 \mathrm{~mL})$ and diisobutylaluminum hydride ( $3 \mathrm{~mL}, 1 \mathrm{M}$ solution in hexanes) and gave $354 \mathrm{mg}$ ( $86 \%$ yield) of product (20).

2-Bromo-1,3-dimethoxy-5-[1-(3-bromopropyl)cyclopentyl]benzene (21). To a stirred solution of 20 ( $400 \mathrm{mg}, 1.17 \mathrm{mmol})$ and carbon tetrabromide $(465 \mathrm{mg}, 1.40 \mathrm{mmol})$ in anhydrous $\mathrm{CH}_{2} \mathrm{Cl}_{2}(10 \mathrm{~mL})$ at $0{ }^{\circ} \mathrm{C}$, under a nitrogen atmosphere, was added triphenylphosphine $(368 \mathrm{mg}, 1.40 \mathrm{mmol}$ ) portionwise. 
After the addition was completed, the reaction mixture was stirred for an additional 20 min, whereupon the solvent was removed in vacuo. The residue was purified by flash column chromatography on silica gel (10\% diethyl ether in hexane) to give 21 as a colorless liquid in $85 \%$ yield $(403 \mathrm{mg}) .{ }^{1} \mathrm{H} \mathrm{NMR}$ $\left(500 \mathrm{MHz} \mathrm{CDCl}_{3}\right) \delta 6.48(\mathrm{~s}, 2 \mathrm{H}, \mathrm{ArH}), 3.89$ (s, 6H, OMe), 3.27 (t, J = 6.4 Hz, 2H, 4'-H), 1.96-1.88 (m, $2 \mathrm{H}$ of the cyclopentane ring), $1.86-1.64\left(\mathrm{~m}, 8 \mathrm{H}, 6 \mathrm{H}\right.$ of the cyclopentane ring and $2^{\prime}-\mathrm{H}$, overlapping), 1.60-1.52 (m, 2H, 3'-H); mass spectrum $m / z$ (relative intensity) $408\left(\mathrm{M}^{+}+4,13\right), 406\left(\mathrm{M}^{+}+2,29\right), 404\left(\mathrm{M}^{+}\right.$, 14), 327 (26), 325 (26), 285 (99), 283 (100), 233 (29), 231 (29), 204 (45), 289 (18), 176 (25), 109 (24), 67 (36); exact mass calculated for $\mathrm{C}_{16} \mathrm{H}_{22} \mathrm{Br}_{2} \mathrm{O}_{2} 403.9987$, found 403.9987 .

2-Bromo-1,3-dimethoxy-5-[1-(3-phenoxypropyl)cyclopentyl]benzene (9c). To a stirred solution of $21(250 \mathrm{mg}, 0.62 \mathrm{mmol})$ in DMSO $(6 \mathrm{~mL})$ at room temperature, under an argon atmosphere, was added sodium phenoxide trihydrate $(530 \mathrm{mg}, 3.10 \mathrm{mmol})$. The reaction mixture was stirred vigorously for $24 \mathrm{~h}$ and then diluted by adding ice water $(5 \mathrm{~mL})$ and diethyl ether. The organic layer was separated, and the aqueous phase was extracted with diethyl ether. The combined organic layer was washed with brine, dried over $\mathrm{MgSO}_{4}$ and evaporated under reduced pressure. Purification by flash column chromatography on silica gel (10\% diethyl ether in hexane) gave $9 \mathrm{c}$ as a colorless liquid in $50 \%$ yield (130 mg). ${ }^{1} \mathrm{H}$ NMR (500 MHz, $\left.\mathrm{CDCl}_{3}\right) \delta 7.24(\mathrm{t}, J=7.5 \mathrm{~Hz}, 2 \mathrm{H}, 3-\mathrm{H}, 5-\mathrm{H}, \mathrm{OPh}), 6.91(\mathrm{t}, J=7.5 \mathrm{~Hz}$, 1H, 4-H, OPh), 6.81 (d, J = 7.5 Hz, 2H, 2-H, 6-H, OPh), 6.51 (s, 2H, ArH), 3.89 (s, 6H, OMe), 3.80 (t, $\left.J=6.5 \mathrm{~Hz}, 2 \mathrm{H}, 4^{\prime}-\mathrm{H}\right), 1.97-1.91(\mathrm{~m}, 2 \mathrm{H}$ of the cyclopentane ring), $1.89-1.83(\mathrm{~m}, 2 \mathrm{H}$ of the cyclopentane ring), $1.79-1.65\left(\mathrm{~m}, 6 \mathrm{H}, 4 \mathrm{H}\right.$ of the cyclopentane ring and $2^{\prime}-\mathrm{H}$, overlapping), 1.53-1.46 (m, 2H, $\left.3^{\prime}-\mathrm{H}\right)$; mass spectrum $\mathrm{m} / \mathrm{z}$ (relative intensity) $420\left(\mathrm{M}^{+}+2,21\right), 418\left(\mathrm{M}^{+}, 21\right), 327(62), 325(62), 285(71), 283(71)$, 231 (99), 229 (100), 204 (38), 151 (47), 109 (10), 67 (35); exact mass calculated for $\mathrm{C}_{22} \mathrm{H}_{27} \mathrm{BrO}_{3}$ 418.1144, found 418.1142 .

2-Bromo-1,3-dimethoxy-5-(1-hexylcyclopentyl)benzene (9d). To a solution of 22 (1 g, $3.45 \mathrm{mmol})$ in anhydrous carbon tetrachloride $(40 \mathrm{~mL})$ at $0{ }^{\circ} \mathrm{C}$, under an argon atmosphere was added bromine ( $7 \mathrm{~mL}, 1 \mathrm{M}$ solution in $\mathrm{CCl}_{4}$ ). The reaction mixture was stirred at the same temperature for $20 \mathrm{~min}$ and the solvent was removed in vacuo. The residue was purified by flash column chromatography on silica gel (5\% diethyl ether in hexane) to give $9 \mathrm{~d}$ as a white solid in $78 \%$ yield $(0.99 \mathrm{~g}) . \mathrm{mp} 38-40{ }^{\circ} \mathrm{C} ;{ }^{1} \mathrm{H}$ NMR $\left(500 \mathrm{MHz}, \mathrm{CDCl}_{3}\right) \delta 6.49$ (s, 2H, ArH), 3.89 (s, 6H, OMe), 1.91-1.85 (m, 2H of the cyclopentane ring), 1.84-1.76 (m, $2 \mathrm{H}$ of the cyclopentane ring), 1.75-1.60 (m, $4 \mathrm{H}$ of the cyclopentane ring), $1.58-1.50$ $\left(\mathrm{m}, 2 \mathrm{H}, 2^{\prime}-\mathrm{H}\right), 1.25-1.09\left(\mathrm{~m}, 6 \mathrm{H}, 4^{\prime}-\mathrm{H}, 5^{\prime}-\mathrm{H}, 6^{\prime}-\mathrm{H}\right), 1.01-0.93\left(\mathrm{~m}, 2 \mathrm{H}, 3^{\prime}-\mathrm{H}\right), 0.83\left(\mathrm{t}, J=7.2 \mathrm{~Hz}, 3 \mathrm{H}, 7^{\prime}-\mathrm{H}\right)$. mass spectrum $m / z$ (relative intensity) $370\left(\mathrm{M}^{+}+2,30\right), 368\left(\mathrm{M}^{+}, 30\right), 285$ (100), 283 (98), 233 (20), 231 (20), 204 (36), 176 (21), 67 (25); exact mass calculated for $\mathrm{C}_{19} \mathrm{H}_{29} \mathrm{BrO}_{2}$ 368.1351, found 368.1351.

4'-[1-(4-Phenoxybutyl)cyclopentyl]-2',5,6'-trimethoxy-N,N-diisopropyl-[1,1'-biphenyl]-2-carboxamide (7a). A degassed mixture of 9a $(135 \mathrm{mg}, 0.31 \mathrm{mmol})$, boronic acid 8 (125 mg, $0.45 \mathrm{mmol}), \mathrm{Ba}(\mathrm{OH})_{2}$ $(160 \mathrm{mg}, 0.93 \mathrm{mmol})$, and $\mathrm{Pd}\left(\mathrm{PPh}_{3}\right)_{4}(70 \mathrm{mg}, 0.06 \mathrm{mmol})$ in DME $(5 \mathrm{~mL}) /$ water $(1 \mathrm{~mL})$ was flushed with argon, and heated in a sealed tube at $80^{\circ} \mathrm{C}$ for $6 \mathrm{~h}$ with vigorous stirring. The reaction mixture was cooled to room temperature and diluted with EtOAc $(30 \mathrm{~mL})$ and the catalyst removed by filtration through celite. The filtrate was diluted with brine, and the organic layer was separated, dried $\left(\mathrm{MgSO}_{4}\right)$, and concentrated in vacuo. Purification by flash column chromatography on silica gel (30\% diethyl ether in hexane) gave $7 \mathbf{a}$ as a viscous liquid in $48 \%$ yield (87 mg). IR (neat) 2927, 2857, 1625, 1607, 1576, 1337, 1241, 1128, $1032 \mathrm{~cm}^{-1}$; ${ }^{1} \mathrm{H}$ NMR $\left(400 \mathrm{MHz}, \mathrm{CDCl}_{3}\right) \delta 7.29$ (t, J = 7.3 Hz, 2H, 3-H, 5-H, -OPh group), 7.27 (d, J = 7.2 Hz, 1H, 3-H, Ph-Ph group), 6.95 (t, J = 7.3 Hz, 1H, 4-H, -OPh group), 6.92-6.86 (d and dd overlapping, 3H, 2-H, 6-H of the -OPh group and 4- $\mathrm{H}$ of the $\mathrm{Ph}-\mathrm{Ph}$ group), $6.82(\mathrm{~d}, J=2.5 \mathrm{~Hz}, 1 \mathrm{H}, 6-\mathrm{H}$, Ph-Ph group), 6.52 (s, 1H, 3'-H or 5'-H, Ph-Ph group), 6.51 (s, 1H, 5'-H or 3'-H, Ph-Ph group), 3.89 (t, $\left.J=6.4 \mathrm{~Hz}, 2 \mathrm{H},-\mathrm{CH}_{2} \mathrm{OPh}\right), 3.84(\mathrm{~s}, 3 \mathrm{H}, \mathrm{OMe}), 3.74(\mathrm{~s}, 3 \mathrm{H}, \mathrm{OMe}), 3.73(\mathrm{~s}, 3 \mathrm{H}, \mathrm{OMe}), 3.71(\mathrm{qt}, J=6.5 \mathrm{~Hz}$, $\left.1 \mathrm{H},-\mathrm{CH}\left(\mathrm{CH}_{3}\right)_{2}\right), 3.16\left(\mathrm{qt}, J=6.5 \mathrm{~Hz}, 1 \mathrm{H},-\mathrm{CH}\left(\mathrm{CH}_{3}\right)_{2}\right), 2.08-1.97(\mathrm{~m}, 2 \mathrm{H}$ of the cyclopentane ring), 1.91-1.60 (m, 10H, $6 \mathrm{H}$ of the cyclopentane ring and $4 \mathrm{H}$ of the 4-phenoxybutyl group, overlapping), 1.46 $\left(\mathrm{d}, J=6.5 \mathrm{~Hz}, 3 \mathrm{H},-\mathrm{CH}\left(\mathrm{CH}_{3}\right)_{2}\right), 1.38-1.25(\mathrm{~m}, 2 \mathrm{H}$ of the 4-phenoxybutyl group), $1.10(\mathrm{~d}, J=6.5 \mathrm{~Hz}, 3 \mathrm{H}$, $\left.-\mathrm{CH}\left(\mathrm{CH}_{3}\right)_{2}\right), 0.92\left(\mathrm{~d}, \mathrm{~J}=6.5 \mathrm{~Hz}, 3 \mathrm{H},-\mathrm{CH}\left(\mathrm{CH}_{3}\right)_{2}\right), 0.58\left(\mathrm{~d}, \mathrm{~J}=6.5 \mathrm{~Hz}, 3 \mathrm{H},-\mathrm{CH}\left(\mathrm{CH}_{3}\right)_{2}\right)$; mass spectrum 
$\mathrm{m} / \mathrm{z}$ (relative intensity) $588\left(\mathrm{M}^{+}+1,22\right), 587\left(\mathrm{M}^{+}, 54\right), 586(29), 556(10), 487$ (84), 395 (100), $323(12), 283$ (15), 262 (44), 183 (20), 91 (11), 67 (9); exact mass calculated for $\mathrm{C}_{37} \mathrm{H}_{49} \mathrm{NO}_{5}$ 587.3611, found 587.3612. 4'-[1-(5-Phenoxypentyl)cyclopentyl]-2', 5,6'-trimethoxy-N,N-diisopropyl-[1,1'-biphenyl]-2carboxamide $(7 \mathrm{~b})$. The synthesis was carried out as described for $7 \mathbf{a}$, using $9 \mathbf{b}(260 \mathrm{mg}, 0.58 \mathrm{mmol})$, $8(242 \mathrm{mg}, 0.87 \mathrm{~mol}), \mathrm{Ba}(\mathrm{OH})_{2}(300 \mathrm{mg}, 1.74 \mathrm{mmol})$, and tetrakis(triphenylphosphine)palladium(0) $(48 \mathrm{mg}, 0.04 \mathrm{mmol})$ in DME $(5 \mathrm{~mL})$ and water $(2 \mathrm{~mL})$. The crude product obtained after workup was chromatographed through a column of silica gel (40\% ethyl acetate in petroleum ether) to give $7 \mathbf{b}$ as a viscous liquid in 50\% yield (175 mg). IR (neat) 2924, 2855, 1624, 1602, 1572, 1335, 1241, 1127, $1030 \mathrm{~cm}^{-1}$; ${ }^{1} \mathrm{H}$ NMR $\left(400 \mathrm{MHz}, \mathrm{CDCl}_{3}\right) \delta 7.19(\mathrm{t}, J=7.3 \mathrm{~Hz}, 2 \mathrm{H}, 3-\mathrm{H}, 5-\mathrm{H},-\mathrm{OPh}$ group), $7.18(\mathrm{~d}, J=7.0 \mathrm{~Hz}, 1 \mathrm{H}, 3-\mathrm{H}$, Ph-Ph group), $6.85(\mathrm{t}, J=7.3 \mathrm{~Hz}, 1 \mathrm{H}, 4-\mathrm{H},-\mathrm{OPh}$ group), 6.82-6.77 (d and dd overlapping, 3H, 2- $\mathrm{H}$, 6-H of the -OPh group and 4- $\mathrm{H}$ of the Ph-Ph group), $6.72(\mathrm{~d}, J=2.6 \mathrm{~Hz}, 1 \mathrm{H}, 6-\mathrm{H}, \mathrm{Ph}-\mathrm{Ph}$ group), 6.41 (s, 1H, 3'-H or 5'-H, Ph-Ph group), $6.40\left(\mathrm{~s}, 1 \mathrm{H}, 5^{\prime}-\mathrm{H}\right.$ or $3^{\prime}-\mathrm{H}, \mathrm{Ph}-\mathrm{Ph}$ group), $3.82(\mathrm{t}, J=6.5 \mathrm{~Hz}, 2 \mathrm{H}$, $\left.-\mathrm{CH}_{2} \mathrm{OPh}\right), 3.73(\mathrm{~s}, 3 \mathrm{H}, \mathrm{OMe}), 3.64(\mathrm{~s}, 3 \mathrm{H}, \mathrm{OMe}), 3.63(\mathrm{~s}, 3 \mathrm{H}, \mathrm{OMe}), 3.61\left(\mathrm{qt}, J=6.6 \mathrm{~Hz}, 1 \mathrm{H},-\mathrm{CH}\left(\mathrm{CH}_{3}\right)_{2}\right)$, $3.06\left(\mathrm{qt}, J=6.6 \mathrm{~Hz}, 1 \mathrm{H},-\mathrm{CH}\left(\mathrm{CH}_{3}\right)_{2}\right), 1.95-1.83(\mathrm{~m}, 2 \mathrm{H}$ of the cyclopentane ring), $1.81-1.51(\mathrm{~m}, 10 \mathrm{H}, 6 \mathrm{H}$ of the cyclopentane ring and $4 \mathrm{H}$ of the 5-phenoxypentyl group, overlapping $), 1.37(\mathrm{~d}, J=6.6 \mathrm{~Hz}, 3 \mathrm{H}$, $\left.-\mathrm{CH}\left(\mathrm{CH}_{3}\right)_{2}\right), 1.25$ (qt, $J=7.7 \mathrm{~Hz}, 2 \mathrm{H}$ of the 5-phenoxypentyl group), 1.10-0.95 ( $\mathrm{m}$ and d overlapping, 5H, especially $\left.1.03, \mathrm{~d}, J=6.6 \mathrm{~Hz}, 3 \mathrm{H},-\mathrm{CH}\left(\mathrm{CH}_{3}\right)_{2}\right), 0.82\left(\mathrm{~d}, J=6.6 \mathrm{~Hz}, 3 \mathrm{H},-\mathrm{CH}\left(\mathrm{CH}_{3}\right)_{2}\right), 0.47(\mathrm{~d}, J=6.6 \mathrm{~Hz}$, $\left.3 \mathrm{H},-\mathrm{CH}\left(\mathrm{CH}_{3}\right)_{2}\right)$; mass spectrum $m / z$ (relative intensity) $602\left(\mathrm{M}^{+}+1,56\right), 601\left(\mathrm{M}^{+}, 84\right), 600(49), 570(20)$, 530 (9), 501 (100), 407 (12), 323 (16), 297 (22), 269 (53), 257 (32), 95 (10), 67 (10); exact mass calculated for $\mathrm{C}_{38} \mathrm{H}_{51} \mathrm{NO}_{5}$ 601.3767, found 601.3765 .

4'-[1-(3-Phenoxypropyl)cyclopentyl]-2',5,6'-trimethoxy-N,N-diisopropyl-[1,1'-biphenyl]-2carboxamide (7c). The synthesis was carried out as described for 7a, using 9c (90 mg, $0.21 \mathrm{mmol})$, $8(108 \mathrm{mg}, 0.39 \mathrm{~mol}), \mathrm{Ba}(\mathrm{OH})_{2}(125 \mathrm{mg}, 0.74 \mathrm{mmol})$ and tetrakis(triphenylphosphine)palladium $(0)$ $(48 \mathrm{mg}, 0.04 \mathrm{mmol})$ in DME $(5 \mathrm{~mL})$ and water $(1 \mathrm{~mL})$. The crude product obtained after workup was chromatographed through a column of silica gel (40\% ethyl acetate in petroleum ether) to give $7 \mathrm{c}$ as a viscous liquid in 50\% yield (60 mg). IR (neat) 2932, 2858, 1624, 1605, 1575, 1342, 1243, 1127, $1032 \mathrm{~cm}^{-1}$; ${ }^{1} \mathrm{H}$ NMR $\left(500 \mathrm{MHz}, \mathrm{CDCl}_{3}\right) \delta 7.26(\mathrm{t}, J=7.7 \mathrm{~Hz}, 2 \mathrm{H}, 3-\mathrm{H}, 5-\mathrm{H},-\mathrm{OPh}$ group), $7.25(\mathrm{~d}, J=8.5 \mathrm{~Hz}, 1 \mathrm{H}$, 3-H, Ph-Ph group), $6.92(\mathrm{t}, J=7.7 \mathrm{~Hz}, 1 \mathrm{H}, 4-\mathrm{H},-\mathrm{OPh}$ group), $6.87(\mathrm{dd}, J=8.5 \mathrm{~Hz}, J=3.0 \mathrm{~Hz}, 1 \mathrm{H}, 4-\mathrm{H}$ of the Ph-Ph group), $6.83(\mathrm{~d}, J=7.7 \mathrm{~Hz}, 2 \mathrm{H}, 2-\mathrm{H}, 6-\mathrm{H}$ of the $-\mathrm{OPh}$ group), $6.79(\mathrm{~d}, J=3.0 \mathrm{~Hz}, 1 \mathrm{H}$, 6-H, Ph-Ph group), 6.52 (s, 1H, 3'-H or 5'-H, Ph-Ph group), 6.50 (s, 1H, 5'-H or 3'-H, Ph-Ph group), $3.81\left(\mathrm{t}, J=6.7 \mathrm{~Hz}, 2 \mathrm{H},-\mathrm{CH}_{2} \mathrm{OPh}\right), 3.80$ (s, 3H, OMe), 3.72 (s, 3H, OMe), 3.71 (s, 3H, OMe), 3.69 (qt, $\left.J=6.5 \mathrm{~Hz}, 1 \mathrm{H},-\mathrm{CH}\left(\mathrm{CH}_{3}\right)_{2}\right), 3.14\left(\mathrm{qt}, J=6.5 \mathrm{~Hz}, 1 \mathrm{H},-\mathrm{CH}\left(\mathrm{CH}_{3}\right)_{2}\right), 2.04-1.94(\mathrm{~m}, 2 \mathrm{H}$ of the cyclopentane ring), $1.88-1.81(\mathrm{~m}, 2 \mathrm{H}$ of the cyclopentane ring), $1.80-1.65(\mathrm{~m}, 6 \mathrm{H}, 4 \mathrm{H}$ of the cyclopentane ring and $-\mathrm{CH}_{2} \mathrm{CH}_{2} \mathrm{CH}_{2} \mathrm{OPh}$, overlapping), 1.60-1.52 (m, 2H, $\left.-\mathrm{CH}_{2} \mathrm{CH}_{2} \mathrm{CH}_{2} \mathrm{OPh}\right), 1.44(\mathrm{~d}, \mathrm{~J}=6.5 \mathrm{~Hz}, 3 \mathrm{H}$, $\left.-\mathrm{CH}\left(\mathrm{CH}_{3}\right)_{2}\right), 1.07\left(\mathrm{~d}, \mathrm{~J}=6.5 \mathrm{~Hz}, 3 \mathrm{H},-\mathrm{CH}\left(\mathrm{CH}_{3}\right)_{2}\right), 0.90\left(\mathrm{~d}, \mathrm{~J}=6.5 \mathrm{~Hz}, 3 \mathrm{H},-\mathrm{CH}\left(\mathrm{CH}_{3}\right)_{2}\right), 0.57(\mathrm{~d}, J=6.5 \mathrm{~Hz}$, $\left.3 \mathrm{H},-\mathrm{CH}\left(\mathrm{CH}_{3}\right)_{2}\right)$; mass spectrum $m / z$ (relative intensity) $574\left(\mathrm{M}^{+}+1,23\right), 573\left(\mathrm{M}^{+}, 65\right), 572(36), 542(13)$, 500 (11), 473 (82), 415 (19), 379 (22), 323 (13), 269 (100), 241 (23), 149 (32), 100 (27); exact mass calculated for $\mathrm{C}_{36} \mathrm{H}_{47} \mathrm{NO}_{5} 573.3454$, found 573.3455 .

4'-(1-Hexyl-cyclopentyl)-2' ,5,6'-trimethoxy-N,N-diisopropyl-[1,1'-biphenyl]-2-carboxamide (7d). The synthesis was carried out as described for 7a, using 9d (90 mg, $0.21 \mathrm{mmol}), 8$ (108 mg, $0.39 \mathrm{~mol})$, $\mathrm{Ba}(\mathrm{OH})_{2}(125 \mathrm{mg}, 0.74 \mathrm{mmol})$, and tetrakis(triphenylphosphine)palladium(0) (48 mg, $\left.0.04 \mathrm{mmol}\right)$ in DME $(5 \mathrm{~mL})$ and water $(1 \mathrm{~mL})$. The crude product obtained after workup was chromatographed through a column of silica gel ( $40 \%$ ethyl acetate in petroleum ether) to give $\mathbf{7 d}$ as a viscous liquid in 50\% yield (60 mg). IR (neat) 2929, 2857, 1605, 1578, $1345 \mathrm{~cm}^{-1},{ }^{1} \mathrm{H} \mathrm{NMR}\left(400 \mathrm{MHz}, \mathrm{CDCl}_{3}\right) \delta 7.26$ (d, $J=8.4 \mathrm{~Hz}, 1 \mathrm{H}, 3-\mathrm{H}, \mathrm{Ph}-\mathrm{Ph}$ group), 6.87 (dd, $J=8.4 \mathrm{~Hz}, J=2.6 \mathrm{~Hz}, 1 \mathrm{H}, 4-\mathrm{H}, \mathrm{Ph}-\mathrm{Ph}$ group), 6.79 (d, $J=2.6 \mathrm{~Hz}, 1 \mathrm{H}, 6-\mathrm{H}$, Ph-Ph group), 6.48 (s, 1H, 3'-H or 5' $-\mathrm{H}, \mathrm{Ph}-\mathrm{Ph}$ group), 6.47 (s, 1H, 5'-H or 3'-H, Ph-Ph group), 3.81 (s, 3H, OMe), 3.72 (s, 3H, OMe), 3.71 (s, 3H, OMe), 3.69 (qt, J = 6.5 Hz, 1H, $\left.-\mathrm{CH}\left(\mathrm{CH}_{3}\right)_{2}\right), 3.17\left(\mathrm{qt}, J=6.5 \mathrm{~Hz}, 1 \mathrm{H},-\mathrm{CH}\left(\mathrm{CH}_{3}\right)_{2}\right), 1.97-1.88(\mathrm{~m}, 2 \mathrm{H}$ of the cyclopentane ring), $1.84-1.76$ (m, $2 \mathrm{H}$ of the cyclopentane ring), 1.75-1.59 (m, $4 \mathrm{H}$ of the cyclopentane ring), 1.57-1.52 (m, 2H, 2' $-\mathrm{H}$, hexyl group), $1.46\left(\mathrm{~d}, \mathrm{~J}=6.5 \mathrm{~Hz}, 3 \mathrm{H},-\mathrm{CH}\left(\mathrm{CH}_{3}\right)_{2}\right), 1.30-1.13\left(\mathrm{~m}, 6 \mathrm{H}, 4^{\prime}-\mathrm{H}, 5^{\prime}-\mathrm{H}, 6^{\prime}-\mathrm{H}\right.$, hexyl group), 1.09 
$\left(\mathrm{d}, J=6.5 \mathrm{~Hz}, 3 \mathrm{H},-\mathrm{CH}\left(\mathrm{CH}_{3}\right)_{2}\right), 1.10-1.01\left(\mathrm{~m}, 2 \mathrm{H}, 3^{\prime}-\mathrm{H}\right.$, hexyl group $), 0.90\left(\mathrm{~d}, J=6.5 \mathrm{~Hz}, 3 \mathrm{H},-\mathrm{CH}\left(\mathrm{CH}_{3}\right)_{2}\right)$, $0.87\left(\mathrm{t}, J=7.1 \mathrm{~Hz}, 3 \mathrm{H}, 7^{\prime}-\mathrm{H}\right.$, hexyl group), $0.56\left(\mathrm{~d}, J=6.5 \mathrm{~Hz}, 3 \mathrm{H},-\mathrm{CH}\left(\mathrm{CH}_{3}\right)_{2}\right) ;$ mass spectrum $\mathrm{m} / \mathrm{z}$ (relative intensity) $524\left(\mathrm{M}^{+}+1,8\right), 523\left(\mathrm{M}^{+}, 24\right) 522$ (18), 492 (6), 450 (5), 423 (100), 337 (5), 269 (5), 235 (5), 192 (8), 135 (35), 94 (27), 57 (19); exact mass calculated for $\mathrm{C}_{33} \mathrm{H}_{49} \mathrm{NO}_{4} 523.3662$, found 523.3664.

4' -[1-(4-Bromobutyl)cyclopentyl]-2' $, 5,6^{\prime}$-trihydroxy-N,N-diisopropyl-[1,1'-biphenyl]-2-carboxamide (23a). To a stirring solution of $7 \mathrm{a}(80.0 \mathrm{mg}, 0.14 \mathrm{mmol})$ in anhydrous $\mathrm{CH}_{2} \mathrm{Cl}_{2}(5 \mathrm{~mL})$, at $-78{ }^{\circ} \mathrm{C}$, under an argon atmosphere, was added boron tribromide $\left(0.7 \mathrm{~mL}, 1 \mathrm{M}\right.$ solution in $\left.\mathrm{CH}_{2} \mathrm{Cl}_{2}\right)$. The mixture was gradually warmed to room temperature and stirred for an additional $12 \mathrm{~h}$. Unreacted boron tribromide was destroyed by the addition of methanol at $0{ }^{\circ} \mathrm{C}$. The resulting mixture was warmed to room temperature and volatiles were removed in vacuo. The residue was diluted with ethyl acetate and washed with saturated $\mathrm{NaHCO}_{3}$ and brine. The organic layer was dried over $\mathrm{MgSO}_{4}$ and the solvent evaporated under reduced pressure. The crude product obtained after workup was purified by flash column chromatography on silica gel (50\% diethyl ether in petroleum ether) to give 23a as a white solid in $92 \%$ yield (68 mg). mp 183-185 ${ }^{\circ} \mathrm{C}$; IR (neat) 3305 (br, OH), 2928, 2852, 1631, 1616, 1570, $1340 \mathrm{~cm}^{-1} ;{ }^{1} \mathrm{H}$ NMR $\left(400 \mathrm{MHz}, \mathrm{CDCl}_{3}\right) \delta 7.92(\mathrm{br} \mathrm{s}, 1 \mathrm{H}, \mathrm{OH}), 7.12$ (d, $J=8.1 \mathrm{~Hz}, 1 \mathrm{H}, 3-\mathrm{H}, \mathrm{Ph}-\mathrm{Ph}$ group), $6.88(\mathrm{dd}, J=8.1 \mathrm{~Hz}, J=2.5 \mathrm{~Hz}, 1 \mathrm{H}, 4-\mathrm{H}$ of the Ph-Ph group), 6.77 (d, $J=2.5 \mathrm{~Hz}, 1 \mathrm{H}, 6-\mathrm{H}, \mathrm{Ph}-\mathrm{Ph}$ group), $6.54\left(\mathrm{~d}, J=1.2 \mathrm{~Hz}, 1 \mathrm{H}, 3^{\prime}-\mathrm{H}\right.$ or $5^{\prime}-\mathrm{H}, \mathrm{Ph}-\mathrm{Ph}$ group), $6.46\left(\mathrm{~d}, J=1.2 \mathrm{~Hz}, 1 \mathrm{H}, 5^{\prime}-\mathrm{H}\right.$ or $3^{\prime}-\mathrm{H}, \mathrm{Ph}-\mathrm{Ph}$ group), $6.19(\mathrm{br} \mathrm{s}, 1 \mathrm{H}, \mathrm{OH}), 4.54(\mathrm{br} \mathrm{s}, 1 \mathrm{H}, \mathrm{OH}), 3.79\left(\mathrm{qt}, J=6.8 \mathrm{~Hz}, 1 \mathrm{H},-\mathrm{CH}\left(\mathrm{CH}_{3}\right)_{2}\right), 3.30(\mathrm{qt}, J=6.8 \mathrm{~Hz}, 1 \mathrm{H}$, $\left.-\mathrm{CH}\left(\mathrm{CH}_{3}\right)_{2}\right), 3.26\left(\mathrm{t}, J=6.5 \mathrm{~Hz}, 2 \mathrm{H},-\mathrm{CH}_{2} \mathrm{Br}\right), 1.93-1.85(\mathrm{~m}, 2 \mathrm{H}$ of the cyclopentane ring), $1.76-1.53(\mathrm{~m}$, $10 \mathrm{H}, 6 \mathrm{H}$ of the cyclopentane ring and $4 \mathrm{H}$ of the 4-bromobutyl group, overlapping), $1.44(\mathrm{~d}, J=6.8 \mathrm{~Hz}$, $\left.3 \mathrm{H},-\mathrm{CH}\left(\mathrm{CH}_{3}\right)_{2}\right), 1.30-1.21\left(\mathrm{~m}, 2 \mathrm{H}\right.$ of the 4-bromobutyl group), $1.07\left(\mathrm{~d}, J=6.8 \mathrm{~Hz}, 3 \mathrm{H},-\mathrm{CH}\left(\mathrm{CH}_{3}\right)_{2}\right)$, $1.06\left(\mathrm{~d}, \mathrm{~J}=6.8 \mathrm{~Hz}, 3 \mathrm{H},-\mathrm{CH}\left(\mathrm{CH}_{3}\right)_{2}\right), 0.86\left(\mathrm{~d}, \mathrm{~J}=6.8 \mathrm{~Hz}, 3 \mathrm{H},-\mathrm{CH}\left(\mathrm{CH}_{3}\right)_{2}\right)$; mass spectrum $\mathrm{m} / \mathrm{z}$ (relative intensity) $533\left(\mathrm{M}^{+}+2,7\right), 531\left(\mathrm{M}^{+}, 7\right), 451$ (16), 433 (10), 431 (10), 351 (18), 295 (21), 268 (8), 241 (12), 102 (32), 86 (100); exact mass calculated for $\mathrm{C}_{28} \mathrm{H}_{38} \mathrm{BrNO}_{4} 531.1984$, found 531.1980.

4'-[1-(5-Bromopentyl)cyclopentyl]-2',5,6'-trihydroxy-N,N-diisopropyl-[1,1'-biphenyl]-2-carboxamide (23b). The synthesis was carried out as described for $\mathbf{2 3 a}$, using $\mathbf{7 b}(165 \mathrm{mg}, 0.27 \mathrm{mmol})$ and $\mathrm{BBr}_{3}$ (1.7 mL, $1 \mathrm{M}$ solution in $\left.\mathrm{CH}_{2} \mathrm{Cl}_{2}\right)$ in anhydrous $\mathrm{CH}_{2} \mathrm{Cl}_{2}(5 \mathrm{~mL})$. The crude product obtained after workup was purified by flash column chromatography on silica gel $(50 \%$ diethyl ether in petroleum ether) to give $23 \mathrm{~b}$ as a white solid in $90 \%$ yield (130 mg). mp 190-192 ${ }^{\circ} \mathrm{C}$; IR (neat) 3312 (br, OH), 2925, 2857, 1632, 1615, 1567, $1343 \mathrm{~cm}^{-1},{ }^{1} \mathrm{H}$ NMR $\left(400 \mathrm{MHz}, \mathrm{CDCl}_{3}\right) \delta 8.16$ (br s, $\left.1 \mathrm{H}, \mathrm{OH}\right), 7.11(\mathrm{~d}, J=8.4 \mathrm{~Hz}$, $1 \mathrm{H}, 3-\mathrm{H}, \mathrm{Ph}-\mathrm{Ph}$ group), $6.84(\mathrm{dd}, J=8.4 \mathrm{~Hz}, J=2.7 \mathrm{~Hz}, 1 \mathrm{H}, 4-\mathrm{H}$ of the $\mathrm{Ph}-\mathrm{Ph}$ group), $6.68(\mathrm{~d}, J=2.7 \mathrm{~Hz}$, $1 \mathrm{H}, 6-\mathrm{H}, \mathrm{Ph}-\mathrm{Ph}$ group), $6.59\left(\mathrm{~d}, J=1.3 \mathrm{~Hz}, 1 \mathrm{H}, 3^{\prime}-\mathrm{H}\right.$ or $5^{\prime}-\mathrm{H}, \mathrm{Ph}-\mathrm{Ph}$ group), $6.47\left(\mathrm{~d}, J=1.3 \mathrm{~Hz}, 1 \mathrm{H}, 5^{\prime}-\mathrm{H}\right.$ or $3^{\prime}-\mathrm{H}, \mathrm{Ph}-\mathrm{Ph}$ group), 6.37 (br s, $\left.1 \mathrm{H}, \mathrm{OH}\right), 4.74(\mathrm{br} \mathrm{s}, 1 \mathrm{H}, \mathrm{OH}), 3.70\left(\mathrm{qt}, J=7.0 \mathrm{~Hz}, 1 \mathrm{H},-\mathrm{CH}\left(\mathrm{CH}_{3}\right)_{2}\right)$, 3.34 (qt, $J=7.0 \mathrm{~Hz}$ and $\mathrm{t} J=6.8 \mathrm{~Hz}$ overlapping, $\left.3 \mathrm{H},-\mathrm{CH}\left(\mathrm{CH}_{3}\right)_{2},-\mathrm{CH}_{2} \mathrm{Br}\right), 1.94-1.85(\mathrm{~m}, 2 \mathrm{H}$ of the cyclopentane ring), $1.79-1.52(\mathrm{~m}, 10 \mathrm{H}, 6 \mathrm{H}$ of the cyclopentane ring and $4 \mathrm{H}$ of the 5-bromopentyl group, overlapping), $1.46\left(\mathrm{~d}, J=7.0 \mathrm{~Hz}, 3 \mathrm{H},-\mathrm{CH}\left(\mathrm{CH}_{3}\right)_{2}\right), 1.28(\mathrm{qt}, J=6.9 \mathrm{~Hz}, 2 \mathrm{H}$ of the 5-bromopentyl group), $1.07\left(\mathrm{~d}, J=7.0 \mathrm{~Hz}, 3 \mathrm{H},-\mathrm{CH}\left(\mathrm{CH}_{3}\right)_{2}\right), 1.06\left(\mathrm{~d}, J=7.0 \mathrm{~Hz}, 3 \mathrm{H},-\mathrm{CH}\left(\mathrm{CH}_{3}\right)_{2}\right), 1.05-0.97(\mathrm{~m}, 2 \mathrm{H}$ of the 5-bromopentyl group), $0.87\left(\mathrm{~d}, J=7.0 \mathrm{~Hz}, 3 \mathrm{H},-\mathrm{CH}\left(\mathrm{CH}_{3}\right)_{2}\right)$; mass spectrum $\mathrm{m} / \mathrm{z}$ (relative intensity) 547 $\left(\mathrm{M}^{+}+2,8\right), 545\left(\mathrm{M}^{+}, 8\right), 465$ (8), 447 (17), 445 (16), 367 (8), 335 (16), 295 (23), 267 (8), 241 (15), 101 (24), 86 (100); exact mass calculated for $\mathrm{C}_{29} \mathrm{H}_{40} \mathrm{BrNO}_{4} 545.2141$, found 545.2145 .

4'-[1-(3-Bromopropyl)cyclopentyl]-2',5,6'-trihydroxy-N,N-diisopropyl-[1,1'-biphenyl]-2-carboxamide (23c). The synthesis was carried out as described for 23a, using $7 \mathrm{c}(52 \mathrm{mg}, 0.09 \mathrm{mmol})$ and $\mathrm{BBr}_{3}(0.6 \mathrm{~mL}$, $1 \mathrm{M}$ solution in $\left.\mathrm{CH}_{2} \mathrm{Cl}_{2}\right)$ in anhydrous $\mathrm{CH}_{2} \mathrm{Cl}_{2}(5 \mathrm{~mL})$. The crude product obtained after workup was purified by flash column chromatography on silica gel (50\% diethyl ether in petroleum ether) to give 23c as a white solid in $91 \%$ yield (42 mg). $\mathrm{mp} 178-180^{\circ} \mathrm{C}$; IR (neat) 3312 (br, OH), 2924, 2855, 1630, 1617, 1572, $1335 \mathrm{~cm}^{-1},{ }^{1} \mathrm{H}$ NMR (500 MHz, $\left.\mathrm{CDCl}_{3}\right) \delta 8.14(\mathrm{br} \mathrm{s}, 1 \mathrm{H}, \mathrm{OH}), 7.13(\mathrm{~d}, J=8.5 \mathrm{~Hz}, 1 \mathrm{H}, 3-\mathrm{H}$, Ph-Ph group), $6.86(\mathrm{dd}, J=8.5 \mathrm{~Hz}, J=2.7 \mathrm{~Hz}, 1 \mathrm{H}, 4-\mathrm{H}$ of the Ph-Ph group), $6.65(\mathrm{~d}, J=2.7 \mathrm{~Hz}, 1 \mathrm{H}, 6-\mathrm{H}$, Ph-Ph group), $6.60\left(\mathrm{~d}, J=1.5 \mathrm{~Hz}, 1 \mathrm{H}, 3^{\prime}-\mathrm{H}\right.$ or $5^{\prime}-\mathrm{H}$, Ph-Ph group), $6.48\left(\mathrm{~d}, J=1.5 \mathrm{~Hz}, 1 \mathrm{H}, 5^{\prime}-\mathrm{H}\right.$ or $3^{\prime}-\mathrm{H}$, Ph-Ph group), 6.30 (br s, 1H, OH), $4.72(\mathrm{br} \mathrm{s}, 1 \mathrm{H}, \mathrm{OH}), 3.71\left(\mathrm{qt}, J=7.0 \mathrm{~Hz}, 1 \mathrm{H},-\mathrm{CH}\left(\mathrm{CH}_{3}\right)_{2}\right), 3.33$ (qt, $\left.J=7.0 \mathrm{~Hz}, 1 \mathrm{H},-\mathrm{CH}\left(\mathrm{CH}_{3}\right)_{2}\right), 3.23\left(\mathrm{t}, J=6.5 \mathrm{~Hz}, 2 \mathrm{H},-\mathrm{CH}_{2} \mathrm{Br}\right), 1.98-1.88(\mathrm{~m}, 2 \mathrm{H}$ of the cyclopentane ring), 
$1.78-1.62\left(\mathrm{~m}, 8 \mathrm{H}, 6 \mathrm{H}\right.$ of the cyclopentane ring and $-\mathrm{CH}_{2} \mathrm{CH}_{2} \mathrm{CH}_{2} \mathrm{Br}$, overlapping $), 1.59-1.53(\mathrm{~m}, 2 \mathrm{H}$, $\left.-\mathrm{CH}_{2} \mathrm{CH}_{2} \mathrm{CH}_{2} \mathrm{Br}\right), 1.45\left(\mathrm{~d}, J=7.0 \mathrm{~Hz}, 3 \mathrm{H},-\mathrm{CH}\left(\mathrm{CH}_{3}\right)_{2}\right), 1.07\left(\mathrm{~d}, J=7.0 \mathrm{~Hz}, 6 \mathrm{H},-\mathrm{CH}\left(\mathrm{CH}_{3}\right)_{2}\right), 0.87(\mathrm{~d}$, $\left.J=7.0 \mathrm{~Hz}, 3 \mathrm{H},-\mathrm{CH}\left(\mathrm{CH}_{3}\right)_{2}\right)$; mass spectrum $\mathrm{m} / \mathrm{z}$ (relative intensity) $519\left(\mathrm{M}^{+}+2,4\right), 517\left(\mathrm{M}^{+}, 4\right), 437(28)$, 336 (56), 296 (22), 294 (24), 241 (9), 102 (43), 86 (100); exact mass calculated for $\mathrm{C}_{27} \mathrm{H}_{36} \mathrm{BrNO}_{4}$ 517.1828, found 517.1830 .

4' -(1-Hexyl-cyclopentyl)-2',5,6'-trihydroxy-N,N-diisopropyl-[1,1'-biphenyl]-2-carboxamide (23d). The synthesis was carried out as described for $23 \mathrm{a}$, using $7 \mathbf{d}(57 \mathrm{mg}, 0.11 \mathrm{mmol})$ and $\mathrm{BBr}_{3}(0.7 \mathrm{~mL}$, $1 \mathrm{M}$ solution in $\left.\mathrm{CH}_{2} \mathrm{Cl}_{2}\right)$ in anhydrous $\mathrm{CH}_{2} \mathrm{Cl}_{2}(5 \mathrm{~mL})$. The crude product obtained after workup was purified by flash column chromatography on silica gel (50\% diethyl ether in petroleum ether) to give 23d as a white solid in $89 \%$ yield (47 mg). mp $185-187^{\circ} \mathrm{C}$; IR (neat) 3295 (br, OH), 2925, 2858, 1632, 1617, $1565,1340 \mathrm{~cm}^{-1} ;{ }^{1} \mathrm{H}$ NMR $\left(400 \mathrm{MHz}, \mathrm{CDCl}_{3}\right) \delta 8.00(\mathrm{br} \mathrm{s}, 1 \mathrm{H}, \mathrm{OH}), 7.15(\mathrm{~d}, J=8.5 \mathrm{~Hz}, 1 \mathrm{H}, 3-\mathrm{H}, \mathrm{Ph}-\mathrm{Ph}$ group), $6.89(\mathrm{dd}, J=8.5 \mathrm{~Hz}, J=2.7 \mathrm{~Hz}, 1 \mathrm{H}, 4-\mathrm{H}$ of the $\mathrm{Ph}-\mathrm{Ph}$ group), $6.75(\mathrm{~d}, J=2.7 \mathrm{~Hz}, 1 \mathrm{H}, 6-\mathrm{H}, \mathrm{Ph}-\mathrm{Ph}$ group), $6.60\left(\mathrm{~d}, J=1.5 \mathrm{~Hz}, 1 \mathrm{H}, 3^{\prime}-\mathrm{H}\right.$ or $5^{\prime}-\mathrm{H}, \mathrm{Ph}-\mathrm{Ph}$ group), $6.47\left(\mathrm{~d}, J=1.5 \mathrm{~Hz}, 1 \mathrm{H}, 5^{\prime}-\mathrm{H}\right.$ or $3^{\prime}-\mathrm{H}, \mathrm{Ph}-\mathrm{Ph}$ group), $5.63(\mathrm{br} \mathrm{s}, 1 \mathrm{H}, \mathrm{OH}), 4.64(\mathrm{br} \mathrm{s}, 1 \mathrm{H}, \mathrm{OH}), 3.71\left(\mathrm{qt}, J=7.0 \mathrm{~Hz}, 1 \mathrm{H},-\mathrm{CH}\left(\mathrm{CH}_{3}\right)_{2}\right), 3.31(\mathrm{qt}, J=7.0 \mathrm{~Hz}$, $\left.1 \mathrm{H},-\mathrm{CH}\left(\mathrm{CH}_{3}\right)_{2}\right), 1.95-1.85(\mathrm{~m}, 2 \mathrm{H}$ of the cyclopentane ring), $1.78-1.59(\mathrm{~m}, 6 \mathrm{H}$ of the cyclopentane ring), $1.57-1.49\left(\mathrm{~m}, 2 \mathrm{H}, 2^{\prime}-\mathrm{H}\right), 1.47\left(\mathrm{~d}, J=7.0 \mathrm{~Hz}, 3 \mathrm{H},-\mathrm{CH}\left(\mathrm{CH}_{3}\right)_{2}\right), 1.25-1.10\left(\mathrm{~m}, 6 \mathrm{H}, 4^{\prime}-\mathrm{H}, 5^{\prime}-\mathrm{H}, 6^{\prime}-\mathrm{H}\right), 1.08$ $\left(\mathrm{d}, J=7.0 \mathrm{~Hz}, 3 \mathrm{H},-\mathrm{CH}\left(\mathrm{CH}_{3}\right)_{2}\right), 1.07\left(\mathrm{~d}, J=7.0 \mathrm{~Hz}, 3 \mathrm{H},-\mathrm{CH}\left(\mathrm{CH}_{3}\right)_{2}\right), 1.04-0.97\left(\mathrm{~m}, 2 \mathrm{H}, 3^{\prime}-\mathrm{H}\right), 0.87(\mathrm{~d}$, $\left.J=7.0 \mathrm{~Hz}, 3 \mathrm{H},-\mathrm{CH}\left(\mathrm{CH}_{3}\right)_{2}\right), 0.82\left(\mathrm{t}, J=7.2 \mathrm{~Hz}, 3 \mathrm{H}, 7^{\prime}-\mathrm{H}\right)$. mass spectrum $\mathrm{m} / z$ (relative intensity) 482 $\left(\mathrm{M}^{+}+1,15\right), 481\left(\mathrm{M}^{+}, 37\right), 86(100)$; exact mass calculated for $\mathrm{C}_{30} \mathrm{H}_{43} \mathrm{NO}_{4} 481.3192$, found 481.3191 .

3-[1-(4-Bromobutyl)cyclopentyl]-1,9-dihydroxy-6H-dibenzo[b,d]pyran-6-one (3a). A stirred solution of 23a (50 mg, $0.094 \mathrm{mmol})$ in glacial acetic acid $(4 \mathrm{~mL})$ and water $(1 \mathrm{~mL})$ was refluxed for $24 \mathrm{~h}$. The reaction mixture was cooled to room temperature and diluted with aqueous $\mathrm{NaHCO}_{3}$ solution $(5 \mathrm{~mL})$ and ethyl acetate $(20 \mathrm{~mL})$. The organic phase was separated, and the aqueous phase extracted with ethyl acetate. The combined organic layer was washed with brine, dried over $\mathrm{MgSO}_{4}$ and concentrated in vacuo. The residue was purified by flash column chromatography on silica gel (60\% diethyl ether in hexanes) to give $3 \mathbf{a}$ as a white solid in $89 \%$ yield (36 mg). mp 96-98 ${ }^{\circ} \mathrm{C}$; IR (neat) 3272 (br, OH), 2941, $1670(>\mathrm{C}=\mathrm{O}), 1611,1272,1110 \mathrm{~cm}^{-1} ;{ }^{1} \mathrm{H} \mathrm{NMR}\left(400 \mathrm{MHz}, \mathrm{CDCl}_{3}\right) \delta 8.45$ $(\mathrm{d}, J=2.4 \mathrm{~Hz}, 1 \mathrm{H}, 10-\mathrm{H}), 8.33(\mathrm{~d}, J=8.7 \mathrm{~Hz}, 1 \mathrm{H}, 7-\mathrm{H}), 7.01(\mathrm{dd}, J=8.7 \mathrm{~Hz}, J=2.4 \mathrm{~Hz}, 1 \mathrm{H}, 8-\mathrm{H})$, $6.88(\mathrm{~d}, J=1.6 \mathrm{~Hz}, 1 \mathrm{H}, 4-\mathrm{H}$ or $2-\mathrm{H}), 6.64(\mathrm{~d}, J=1.6 \mathrm{~Hz}, 1 \mathrm{H}, 2-\mathrm{H}$ or $4-\mathrm{H}), 6.32-5.50(\mathrm{br} \mathrm{s}, 2 \mathrm{H}, \mathrm{OH})$, $3.29\left(\mathrm{t}, J=6.8 \mathrm{~Hz}, 2 \mathrm{H},-\mathrm{CH}_{2} \mathrm{Br}\right), 1.97-1.87(\mathrm{~m}, 2 \mathrm{H}$ of the cyclopentane ring), $1.86-1.51(\mathrm{~m}, 10 \mathrm{H}, 6 \mathrm{H}$ of the cyclopentane ring and $4 \mathrm{H}$ of the 4-bromobutyl group, overlapping), $1.21-1.10(\mathrm{~m}, 2 \mathrm{H}$ of the 4-bromobutyl group); ${ }^{13} \mathrm{C}$ NMR (100 MHz, $\left.\mathrm{CD}_{3} \mathrm{OD}\right) \delta$ 165.2, 163.9, 157.7, 154.0, 153.0, 138.9, 133.3, 117.0, 113.9, 113.1, 111.6, 107.9, 105.8, 52.4, 42.0, 38.7, 34.5, 34.2, 25.2, 24.2; mass spectrum $\mathrm{m} / \mathrm{z}$ (relative intensity) $432\left(\mathrm{M}^{+}+2,8\right), 430\left(\mathrm{M}^{+}, 8\right), 350(11), 321$ (33), 295 (100), 267 (15), 91(3). exact mass calculated for $\mathrm{C}_{22} \mathrm{H}_{23} \mathrm{BrO}_{4} 430.0780$, found 430.0778 .

3-[1-(5-Bromopentyl)cyclopentyl]-1,9-dihydroxy-6H-dibenzo[b,d]pyran-6-one (3b). The synthesis was carried out as described for $\mathbf{3 a}$ using $\mathbf{2 3} \mathbf{b}(55 \mathrm{mg}, 0.10 \mathrm{mmol})$ in glacial acetic acid $(4 \mathrm{~mL})$ and water $(1 \mathrm{~mL})$ and gave $3 \mathbf{b}$ as a white solid in $90 \%$ yield $(40 \mathrm{mg}) . \mathrm{mp} 101-103^{\circ} \mathrm{C}$; IR (neat) $3275(\mathrm{br}, \mathrm{OH})$, 2923, $1668(>\mathrm{C}=\mathrm{O}), 1607,1272,1105 \mathrm{~cm}^{-1} ;{ }^{1} \mathrm{H}$ NMR $\left(500 \mathrm{MHz}, \mathrm{CDCl}_{3}\right) \delta 8.37(\mathrm{~d}, J=2.1 \mathrm{~Hz}, 1 \mathrm{H}, 10-\mathrm{H})$, $8.27(\mathrm{~d}, J=8.3 \mathrm{~Hz}, 1 \mathrm{H}, 7-\mathrm{H}), 6.94(\mathrm{dd}, J=8.3 \mathrm{~Hz}, J=2.1 \mathrm{~Hz}, 1 \mathrm{H}, 8-\mathrm{H}), 6.81(\mathrm{~d}, J=1.1 \mathrm{~Hz}, 1 \mathrm{H}, 4-\mathrm{H}$ or 2-H), $6.56(\mathrm{~d}, J=1.1 \mathrm{~Hz}, 1 \mathrm{H}, 2-\mathrm{H}$ or $4-\mathrm{H}), 6.02(\mathrm{br} \mathrm{s}, 1 \mathrm{H}, \mathrm{OH}), 5.87(\mathrm{br} \mathrm{s}, 1 \mathrm{H}, \mathrm{OH}), 3.24(\mathrm{t}, J=6.7 \mathrm{~Hz}, 2 \mathrm{H}$, $\left.-\mathrm{CH}_{2} \mathrm{Br}\right), 1.89-1.80(\mathrm{~m}, 2 \mathrm{H}$ of the cyclopentane ring), $1.76-1.48(\mathrm{~m}, 10 \mathrm{H}, 6 \mathrm{H}$ of the cyclopentane ring and $4 \mathrm{H}$ of the 5-bromopentyl group, overlapping), 1.22 ( $\mathrm{qt}, J=6.5 \mathrm{~Hz}, 2 \mathrm{H}$ of the 5-bromopentyl group), 1.01-0.89 (m, $2 \mathrm{H}$ of the 5-bromopentyl group); ${ }^{13} \mathrm{C} \mathrm{NMR}\left(100 \mathrm{MHz}, \mathrm{CD}_{3} \mathrm{OD}\right) \delta 165.2,163.9,157.7,154.0$, 153.2, 138.9, 133.3, 116.9, 113.9, 113.1, 111.6, 107.9, 105.8, 52.4, 42.8, 38.7, 34.3, 33.9, 29.8, 25.8, 24.2; mass spectrum $m / z$ (relative intensity) $446\left(\mathrm{M}^{+}+2,10\right), 444\left(\mathrm{M}^{+}, 10\right), 364$ (11), 335 (28), 295 (100), 267 (16), 241 (42), 91(5), 67 (14); exact mass calculated for $\mathrm{C}_{23} \mathrm{H}_{25} \mathrm{BrO}_{4} 444.0936$, found 444.0930 .

3-[1-(3-Bromopropyl)cyclopentyl]-1,9-dihydroxy-6H-dibenzo[b,d]pyran-6-one (3c). The synthesis was carried out as described for $3 a$ using $23 \mathrm{c}(30 \mathrm{mg}, 0.058 \mathrm{mmol})$ in glacial acetic acid $(4 \mathrm{~mL})$ and water $(1 \mathrm{~mL})$ and gave $3 \mathrm{c}$ as a white solid in $91 \%$ yield $(22 \mathrm{mg}) . \mathrm{mp} 105-106{ }^{\circ} \mathrm{C}$; IR (neat) 3285 (br, 
$\mathrm{OH}), 2928,1668$ (>C=O), 1610, 1272, $1110 \mathrm{~cm}^{-1} ;{ }^{1} \mathrm{H}$ NMR $\left(500 \mathrm{MHz}, \mathrm{CDCl}_{3}\right) \delta 8.49(\mathrm{~d}, J=2.0 \mathrm{~Hz}$, $1 \mathrm{H}, 10-\mathrm{H}), 8.32(\mathrm{~d}, J=8.3 \mathrm{~Hz}, 1 \mathrm{H}, 7-\mathrm{H}), 7.00(\mathrm{dd}, J=8.3 \mathrm{~Hz}, J=2.0 \mathrm{~Hz}, 1 \mathrm{H}, 8-\mathrm{H}), 6.67(\mathrm{~d}, J=1.4 \mathrm{~Hz}$, $1 \mathrm{H}, 4-\mathrm{H}$ or $2-\mathrm{H}), 6.52(\mathrm{~d}, J=1.4 \mathrm{~Hz}, 1 \mathrm{H}, 2-\mathrm{H}$ or $4-\mathrm{H}), 6.35-5.89(\mathrm{br} \mathrm{s}, 2 \mathrm{H}, \mathrm{OH}), 3.25(\mathrm{t}, J=6.5 \mathrm{~Hz}, 2 \mathrm{H}$, $\left.-\mathrm{CH}_{2} \mathrm{Br}\right), 1.96-1.86(\mathrm{~m}, 2 \mathrm{H}$ of the cyclopentane ring), $1.77-1.60(\mathrm{~m}, 8 \mathrm{H}, 6 \mathrm{H}$ of the cyclopentane ring and $-\mathrm{CH}_{2} \mathrm{CH}_{2} \mathrm{CH}_{2} \mathrm{Br}$, overlapping), $1.57-1.52\left(\mathrm{~m}, 2 \mathrm{H},-\mathrm{CH}_{2} \mathrm{CH}_{2} \mathrm{CH}_{2} \mathrm{Br}\right)$, mass spectrum $\mathrm{m} / \mathrm{z}$ (relative intensity) $418\left(\mathrm{M}^{+}+2,6\right), 416\left(\mathrm{M}^{+}, 6\right), 336(9), 307$ (25), 295 (100), 267 (18), 91(3); exact mass calculated for $\mathrm{C}_{21} \mathrm{H}_{21} \mathrm{BrO}_{4} 416.0623$, found 416.0627 .

3-(1-Hexyl-cyclopentyl]-1,9-dihydroxy-6H-dibenzo[b,d]pyran-6-one (3d). The synthesis was carried out as described for 3a, using $23 \mathrm{~d}(40 \mathrm{mg}, 0.083 \mathrm{mmol})$ in glacial acetic acid $(4 \mathrm{~mL})$ and water $(1 \mathrm{~mL})$, and gave $3 \mathrm{~d}$ as a white solid in $91 \%$ yield $(28 \mathrm{mg}) . \mathrm{mp} 153-155^{\circ} \mathrm{C}$; IR (neat) 3278 (br, OH), 2925, $1667(>\mathrm{C}=\mathrm{O}), 1614,1384,1275,1108 \mathrm{~cm}^{-1} ;{ }^{1} \mathrm{H}$ NMR $\left(500 \mathrm{MHz}, \mathrm{CDCl}_{3}\right) \delta 8.41(\mathrm{~d}, J=2.4 \mathrm{~Hz}, 1 \mathrm{H}, 10-\mathrm{H})$, $8.33(\mathrm{~d}, J=8.7 \mathrm{~Hz}, 1 \mathrm{H}, 7-\mathrm{H}), 7.00(\mathrm{dd}, J=8.7 \mathrm{~Hz}, J=2.4 \mathrm{~Hz}, 1 \mathrm{H}, 8-\mathrm{H}), 6.90(\mathrm{~d}, J=1.6 \mathrm{~Hz}, 1 \mathrm{H}, 4-\mathrm{H}$ or 2-H), $6.61(\mathrm{~d}, J=1.6 \mathrm{~Hz}, 1 \mathrm{H}, 2-\mathrm{H}$ or $4-\mathrm{H}), 5.65(\mathrm{br} \mathrm{s}, 1 \mathrm{H}, \mathrm{OH}), 5.50(\mathrm{br} \mathrm{s}, 1 \mathrm{H}, \mathrm{OH}), 1.94-1.87(\mathrm{~m}, 2 \mathrm{H}$ of the cyclopentane ring), $1.82-1.62\left(\mathrm{~m}, 6 \mathrm{H}\right.$ of the cyclopentane ring), $1.60-1.52\left(\mathrm{~m}, 2 \mathrm{H}, 2^{\prime}-\mathrm{H}\right), 1.24-1.12$ $\left(\mathrm{m}, 6 \mathrm{H}, 4^{\prime}-\mathrm{H}, 5^{\prime}-\mathrm{H}, 6^{\prime}-\mathrm{H}\right), 1.03-0.94\left(\mathrm{~m}, 2 \mathrm{H}, 3^{\prime}-\mathrm{H}\right), 0.82\left(\mathrm{t}, J=6.9 \mathrm{~Hz}, 3 \mathrm{H}, 7^{\prime}-\mathrm{H}\right) ;{ }^{13} \mathrm{C}$ NMR $(100 \mathrm{MHz}$, $\left.\mathrm{CD}_{3} \mathrm{OD}\right) \delta 165.2,164.0,157.7,153.9,153.3,139.0,133.3,116.9,113.9,113.0,111.7,107.9,105.7,52.5,43.0$, $38.8,32.9,31.0,26.5,24.3,23.7,14.4$; mass spectrum $\mathrm{m} / \mathrm{z}$ (relative intensity) $381\left(\mathrm{M}^{+}+1,6\right), 380\left(\mathrm{M}^{+}\right.$, 18), 295 (4), 270 (23), 241 (11), 205 (71), 149 (62), 135 (80), 91 (63), 83 (54), 69 (37), 59 (100); exact mass calculated for $\mathrm{C}_{24} \mathrm{H}_{28} \mathrm{O}_{4} 380.1988$, found 380.1986 .

3-[1-(4-Cyanobutyl)cyclopentyl]-1,9-dihydroxy-6H-dibenzo[b,d]pyran-6-one (3e). To a stirring solution of $3 \mathbf{a}$ ( $30 \mathrm{mg}, 0.07 \mathrm{mmol})$ in anhydrous DMSO $(5 \mathrm{~mL})$, at room temperature, under an argon atmosphere, was added and $\mathrm{NaCN}(17 \mathrm{mg}, 0.35 \mathrm{mmol})$. The reaction mixture was stirred vigorously for $24 \mathrm{~h}$ and then diluted by adding ice water $(2 \mathrm{~mL})$ and diethyl ether $(10 \mathrm{~mL})$. The organic layer was separated, and the aqueous phase was extracted with diethyl ether $(2 \times 5 \mathrm{~mL})$. The combined organic layer was washed with brine, dried over $\mathrm{MgSO}_{4}$ and concentrated under reduced pressure. The crude material was purified by flash column chromatography on silica gel ( $40 \%$ ethyl acetate in petroleum ether) gave $3 \mathbf{e}$ as a white solid in $72 \%$ yield (19 mg). mp $138-140{ }^{\circ} \mathrm{C}$; IR (neat) 3275 (br, OH), 2925, 2853, $2259(\mathrm{w}, \mathrm{C} \equiv \mathrm{N}), 1684(>\mathrm{C}=\mathrm{O}), 1602,1270,1107 \mathrm{~cm}^{-1} ;{ }^{1} \mathrm{H}$ NMR $\left(400 \mathrm{MHz}, \mathrm{CDCl}_{3}\right) \delta 9.82$ (br s, $1 \mathrm{H}, \mathrm{OH}), 9.78(\mathrm{br} \mathrm{s}, 1 \mathrm{H}, \mathrm{OH}), 8.60(\mathrm{~d}, J=2.3 \mathrm{~Hz}, 1 \mathrm{H}, 10-\mathrm{H}), 8.22(\mathrm{~d}, J=8.7 \mathrm{~Hz}, 1 \mathrm{H}, 7-\mathrm{H}), 6.98(\mathrm{dd}$, $J=8.7 \mathrm{~Hz}, J=2.3 \mathrm{~Hz}, 1 \mathrm{H}, 8-\mathrm{H}), 6.78(\mathrm{~d}, J=1.7 \mathrm{~Hz}, 1 \mathrm{H}, 4-\mathrm{H}$ or $2-\mathrm{H}), 6.77(\mathrm{~d}, J=1.7 \mathrm{~Hz}, 1 \mathrm{H}, 2-\mathrm{H}$ or $4-\mathrm{H}), 2.24\left(\mathrm{t}, J=7.1 \mathrm{~Hz}, 2 \mathrm{H},-\mathrm{CH}_{2} \mathrm{CN}\right), 1.99-1.89(\mathrm{~m}, 2 \mathrm{H}$ of the cyclopentane ring), $1.80-1.57(\mathrm{~m}, 8 \mathrm{H}, 6 \mathrm{H}$ of the cyclopentane ring and $2 \mathrm{H}$ of the 4 -cyanobutyl group, overlapping), 1.53 (qt, $J=7.6 \mathrm{~Hz}, 2 \mathrm{H}$ of the 4-cyanobutyl group), $1.23-1.11$ ( $\mathrm{m}, 2 \mathrm{H}$ of the 4-cyanobutyl group); mass spectrum $\mathrm{m} / \mathrm{z}$ (relative intensity) $378\left(\mathrm{M}^{+}+1,8\right), 377\left(\mathrm{M}^{+}, 27\right), 368$ (5), 309 (5), 295 (100), 279 (98), 241 (27), 224 (31), 205 (20), 91 (13), 67 (14); exact mass calculated for $\mathrm{C}_{23} \mathrm{H}_{23} \mathrm{NO}_{4} 377.1627$, found 377.1625.

3-[1-(5-Cyanopentyl)cyclopentyl]-1,9-dihydroxy-6H-dibenzo[b,d]pyran-6-one (3f). The synthesis was carried out as described for $\mathbf{3 e}$, using $3 \mathbf{b}(31 \mathrm{mg}, 0.07 \mathrm{mmol})$ and $\mathrm{NaCN}$ ( $17 \mathrm{mg}, 0.35 \mathrm{mmol})$ in DMSO $(5 \mathrm{~mL})$, and gave $3 \mathrm{f}$ as a white solid in $69 \%$ yield $(19 \mathrm{mg}) . \mathrm{mp} 176-178{ }^{\circ} \mathrm{C}$; IR (neat) 3281 (br, $\mathrm{OH}), 2923,2854,2259(\mathrm{w}, \mathrm{C} \equiv \mathrm{N}), 1683$ (>C=O), 1618, 1598, 1271, 1216, $1103 \mathrm{~cm}^{-1} ;{ }^{1} \mathrm{H}$ NMR $(500 \mathrm{MHz}$, $\left.\mathrm{CDCl}_{3}\right) \delta 8.45(\mathrm{~d}, J=2.0 \mathrm{~Hz}, 1 \mathrm{H}, 10-\mathrm{H}), 8.33(\mathrm{~d}, J=8.2 \mathrm{~Hz}, 1 \mathrm{H}, 7-\mathrm{H}), 7.02(\mathrm{dd}, J=8.2 \mathrm{~Hz}, J=2.0 \mathrm{~Hz}, 1 \mathrm{H}$, $8-\mathrm{H}), 6.88(\mathrm{~d}, J=1.2 \mathrm{~Hz}, 1 \mathrm{H}, 4-\mathrm{H}$ or $2-\mathrm{H}), 6.65(\mathrm{~d}, J=1.2 \mathrm{~Hz}, 1 \mathrm{H}, 2-\mathrm{H}$ or $4-\mathrm{H}), 6.20(\mathrm{br} \mathrm{s}, 1 \mathrm{H}, \mathrm{OH}), 5.87$ (br s, $1 \mathrm{H}, \mathrm{OH}), 2.26\left(\mathrm{t}, J=6.8 \mathrm{~Hz}, 2 \mathrm{H},-\mathrm{CH}_{2} \mathrm{CN}\right), 1.97-1.90(\mathrm{~m}, 2 \mathrm{H}$ of the cyclopentane ring), 1.81-1.52 (m, $10 \mathrm{H}, 6 \mathrm{H}$ of the cyclopentane ring and $4 \mathrm{H}$ of the 5 -cyanopentyl group, overlapping), 1.35 (qt, $J=7.3 \mathrm{~Hz}$, $2 \mathrm{H}$ of the 5-cyanopentyl group), $1.10-1.03$ ( $\mathrm{m}, 2 \mathrm{H}$ of the 5-cyanopentyl group); ${ }^{13} \mathrm{C} \mathrm{NMR} \mathrm{(100} \mathrm{MHz,}$ $\left.\mathrm{CD}_{3} \mathrm{OD}\right) \delta 165.2,163.9,157.7,154.0,153.1,138.9,133.3,121.2,116.9,113.9,113.1,111.6,107.9,105.8,52.4$, 42.7, 38.7, 30.4, 26.4, 25.9, 24.2, 17.3; mass spectrum $m / z$ (relative intensity) $392\left(\mathrm{M}^{+}+1,15\right), 391\left(\mathrm{M}^{+}, 44\right)$, 349 (4), 306 (100), 295 (15), 266 (11), 252 (28), 240 (12), 190 (4), 149 (6), 67 (10); exact mass calculated for $\mathrm{C}_{24} \mathrm{H}_{25} \mathrm{NO}_{4} 391.1784$, found 391.1781 .

3-[1-(3-Cyanopropyl)cyclopentyl]-1,9-dihydroxy-6H-dibenzo[b,d]pyran-6-one (3g). The synthesis was carried out as described for $3 \mathbf{e}$, using $3 \mathbf{c}(18 \mathrm{mg}, 0.043 \mathrm{mmol})$ and $\mathrm{NaCN}(11 \mathrm{mg}, 0.22 \mathrm{mmol})$ in 
DMSO (5 mL) and gave $3 \mathrm{~g}$ as a white solid in $70 \%$ yield $(13 \mathrm{mg}) . \mathrm{mp} 118-120{ }^{\circ} \mathrm{C}$; IR (neat) 3285 (br, $\mathrm{OH}), 2928,2853,2260(\mathrm{w}, \mathrm{C} \equiv \mathrm{N}), 1683$ (>C=O), 1599, 1272, $1105 \mathrm{~cm}^{-1} ;{ }^{1} \mathrm{H}$ NMR $\left(500 \mathrm{MHz}, \mathrm{CDCl}_{3}\right) \delta$ $8.47(\mathrm{~d}, J=2.1 \mathrm{~Hz}, 1 \mathrm{H}, 10-\mathrm{H}), 8.31(\mathrm{~d}, J=8.3 \mathrm{~Hz}, 1 \mathrm{H}, 7-\mathrm{H}), 6.98(\mathrm{dd}, J=8.3 \mathrm{~Hz}, J=2.1 \mathrm{~Hz}, 1 \mathrm{H}, 8-\mathrm{H})$, $6.64(\mathrm{~d}, J=1.3 \mathrm{~Hz}, 1 \mathrm{H}, 4-\mathrm{H}$ or $2-\mathrm{H}), 6.49(\mathrm{~d}, J=1.3 \mathrm{~Hz}, 1 \mathrm{H}, 2-\mathrm{H}$ or $4-\mathrm{H}), 6.22$ (br s, 1H, OH), 5.78 (br s, $1 \mathrm{H}, \mathrm{OH}), 2.23\left(\mathrm{t}, \mathrm{J}=6.7 \mathrm{~Hz}, 2 \mathrm{H},-\mathrm{CH}_{2} \mathrm{CN}\right), 1.94-1.83(\mathrm{~m}, 2 \mathrm{H}$ of the cyclopentane ring), 1.74-1.56 (m, 8H, $6 \mathrm{H}$ of the cyclopentane ring and $-\mathrm{CH}_{2} \mathrm{CH}_{2} \mathrm{CH}_{2} \mathrm{CN}$, overlapping), $1.55-1.49\left(\mathrm{~m}, 2 \mathrm{H},-\mathrm{CH}_{2} \mathrm{CH}_{2} \mathrm{CH}_{2} \mathrm{CN}\right)$; mass spectrum $\mathrm{m} / \mathrm{z}$ (relative intensity) $364\left(\mathrm{M}^{+}+1,7\right), 363\left(\mathrm{M}^{+}, 22\right), 336(67), 309(24), 295(100), 279$ (48), 241 (47), 165 (10), 129 (24); exact mass calculated for $\mathrm{C}_{22} \mathrm{H}_{21} \mathrm{NO}_{4} 363.1471$, found 363.1470.

Radioligand binding assays: the affinities $\left(K_{\mathrm{i}}\right)$ of the new compounds for rat CB1 receptor as well as for mouse and human CB2 receptors were obtained by using membrane preparations from rat brain or HEK293 cells expressing either mCB2 or hCB2 receptors, respectively, and $\left[{ }^{3} \mathrm{H}\right] \mathrm{CP}-55,940$ as the radioligand, as previously described $[38,57]$. Results from the competition assays were analyzed using nonlinear regression to determine the $\mathrm{IC}_{50}$ values for the ligand [59]; $K_{\mathrm{i}}$ values were calculated from the $\mathrm{IC}_{50}$ (Prism by GraphPad Software, Inc.). Each experiment was performed in triplicate and $K_{\mathrm{i}}$ values determined from three independent experiments and are expressed as the mean of the three values.

cAMP assay: $[57,60]$ HEK293 cells stably expressing hCB2 receptors were used for the studies. The cAMP assay was carried out using PerkinElmer's Lance ultra cAMP kit following the protocol of the manufacturer. Briefly, the assays were carried out in 384-well plates using 1000-1500 cells/well. The cells were harvested with non-enzymatic cell dissociation reagent Versene, washed once with HBSS and resuspended in the stimulation buffer. The various concentrations of the test compound (5 $\mu \mathrm{L})$ in forskolin ( $2 \mu \mathrm{M}$ final concentration) containing stimulation buffer were added to the plate followed by the cell suspension $(5 \mu \mathrm{L})$. Cells were stimulated for $30 \mathrm{~min}$ at room temperature. Eu-cAMP tracer working solution $(5 \mu \mathrm{L})$ and Ulight-anti-cAMP working solution $(5 \mu \mathrm{L})$ were then added to the plate and incubated at room temperature for $60 \mathrm{~min}$. The data were collected on a Perkin-Elmer Envision instrument. The $\mathrm{EC}_{50}$ values were determined by non-linear regression analysis using GraphPad Prism software (GraphPad Software, Inc., San Diego, CA, USA).

\section{Conclusions}

This study expands on earlier work on the CB2-selective cannabilactone prototype. We explored the effects of modifications to the pharmacophoric side chain. In particular, we replaced the C1'-gem-dimethyl group in AM1714 with the bulkier cyclopentyl ring, varied the chain's length, and substituted a bromo or cyano group for the terminal carbon. We identified the analog 6-[1-(1,9-dihydroxy-6-oxo-6H-benzo[c]chromen-3-yl)cyclopentyl]hexanenitrile (AM4346) as a high-affinity ligand to $\mathrm{mCB} 2\left(K_{\mathrm{i}}=4.9 \mathrm{nM}\right)$ with 131-fold selectivity for $\mathrm{mCB} 2$ over rCB1. Moreover, the species difference in the affinities of AM4346 between the mouse and the human CB2 receptors is reduced when compared to our first-generation compound AM1714. Importantly, in the cyclase assay AM4346 was found to be a highly potent and efficacious $\mathrm{hCB} 2$ receptor agonist $\left(\mathrm{EC}_{50}=3.7 \pm 1.5 \mathrm{nM}, E_{(\max )}=89 \%\right)$. Our lead cannabilactone analog, AM4346, is also endowed with enhanced polarity due to the incorporation of the cyano group. Extension of our SAR to include the biphenyl synthetic intermediates has revealed new compounds that bind $\mathrm{mCB} 2$ with high affinity and substantial selectivity for that receptor over rCB1.

Author Contributions: Conceptualization, A.M. and S.P.N.; Methodology, S.O.A. and S.P.N.; Validation, A.M., S.P.N., S.O.A., T.C.H.; Formal Analysis, A.M., S.P.N. and S.O.A.; Biological Investigation, F.T., O.B. and S.P.N.; Writing-Original Draft Preparation, S.O.A., S.P.N, and T.C.H.; Writing-Review and Editing, S.P.N.; Supervision, A.M. and S.P.N.; Funding Acquisition, A.M.

Funding: This research was funded by the National Institute on Drug Abuse: grand numbers DA009158, DA045020, and DA041307-01.

Conflicts of Interest: The authors declare no conflict of interest. 


\section{References}

1. Devane, W.A.; Dysarz, F.A.; Johnson, M.R.; Melvin, L.S.; Howlett, A.C. Determination and characterization of a cannabinoid receptor in rat brain. Mol. Pharm. 1988, 34, 605-613.

2. Munro, S.; Thomas, K.L.; Abu-Shaar, M. Molecular characterization of a peripheral receptor for cannabinoids. Nature 1993, 365, 61-65. [CrossRef] [PubMed]

3. Matsuda, L.A.; Lolait, S.J.; Brownstein, M.J.; Young, A.C.; Bonner, T.I. Structure of a cannabinoid receptor and functional expression of the cloned cDNA. Nature 1990, 346, 561-564. [CrossRef] [PubMed]

4. Console-Bram, L.; Marcu, J.; Abood, M.E. Cannabinoid receptors: Nomenclature and pharmacological principles. Prog. Neuropsychopharmacol. Biol. Psychiatry 2012, 38, 4-15. [CrossRef] [PubMed]

5. Shire, D.; Calandra, B.; Rinaldi-Carmona, M.; Oustric, D.; Pessegue, B.; Bonnin-Cabanne, O.; Le Fur, G.; Caput, D.; Ferrara, P. Molecular cloning, expression and function of the murine CB2 peripheral cannabinoid receptor. Biochim. Biophys. Acta 1996, 1307, 132-136. [CrossRef]

6. Griffin, G.; Tao, Q.; Abood, M.E. Cloning and pharmacological characterization of the rat CB2 cannabinoid receptor. J. Pharm. Exp. 2000, 292, 886-894.

7. Howlett, A.C.; Barth, F.; Bonner, T.I.; Cabral, G.; Casellas, P.; Devane, W.A.; Felder, C.C.; Herkenham, M.; Mackie, K.; Martin, B.R.; et al. International Union of Pharmacology. XXVII. Classification of cannabinoid receptors. Pharm. Rev. 2002, 54, 161-202. [CrossRef] [PubMed]

8. Mackie, K. Cannabinoid receptors: Where they are and what they do. J. Neuroendocr. 2008, 20, 10-14. [CrossRef]

9. Li, X.; Hua, T.; Vemuri, K.; Ho, J.H.; Wu, Y.; Wu, L.; Popov, P.; Benchama, O.; Zvonok, N.; Locke, K.; et al. Crystal structure of the human cannabinoid receptor CB2. Cell 2019, 176, 459-467. [CrossRef]

10. Shao, Z.; Yin, J.; Chapman, K.; Grzemska, M.; Clark, L.; Wang, J.; Rosenbaum, D.M. High-resolution crystal structure of the human CB1 cannabinoid receptor. Nature 2016, 540, 602-606. [CrossRef]

11. Hua, T.; Vemuri, K.; Nikas, S.P.; Laprairie, R.B.; Wu, Y.; Qu, L.; Pu, M.; Korde, A.; Jiang, S.; Ho, J.H.; et al. Crystal structures of agonist-bound human cannabinoid receptor CB1. Nature 2017, 547, 468-471. [CrossRef] [PubMed]

12. Hua, T.; Vemuri, K.; Pu, M.C.; Qu, L.; Han, G.W.; Wu, Y.R.; Zhao, S.W.; Shui, W.Q.; Li, S.S.; Korde, A.; et al. Crystal structure of the human cannabinoid receptor CB1. Cell 2016, 167, 750-762. [CrossRef] [PubMed]

13. Thompson, M.D.; Sakurai, T.; Rainero, I.; Maj, M.C.; Kukkonen, J.P. Orexin receptor multimerization versus functional interactions: Neuropharmacological implications for opioid and cannabinoid signalling and pharmacogenetics. Pharmaceuticals 2017, 10, 79. [CrossRef] [PubMed]

14. Abood, M.E.; Martin, B.R. Neurobiology of marijuana abuse. Trends Pharm. Sci. 1992, 13, 201-206. [CrossRef]

15. Ibrahim, M.M.; Porreca, F.; Lai, J.; Albrecht, P.J.; Rice, F.L.; Khodorova, A.; Davar, G.; Makriyannis, A.; Vanderah, T.W.; Mata, H.P.; et al. CB2 cannabinoid receptor activation produces antinociception by stimulating peripheral release of endogenous opioids. Proc. Natl. Acad. Sci. USA 2005, 102, 3093-3098. [CrossRef]

16. Iwamura, H.; Suzuki, H.; Ueda, Y.; Kaya, T.; Inaba, T. In vitro and in vivo pharmacological characterization of JTE-907, a novel selective ligand for cannabinoid CB2 receptor. J. Pharm. Exp. 2001, 296, 420-425.

17. Jonsson, K.O.; Holt, S.; Fowler, C.J. The endocannabinoid system: Current pharmacological research and therapeutic possibilities. Basic Clin. Pharm. Toxicol. 2006, 98, 124-134. [CrossRef]

18. Kangas, B.D.; Leonard, M.Z.; Shukla, V.G.; Alapafuja, S.O.; Nikas, S.P.; Makriyannis, A.; Bergman, J. Comparisons of delta9-tetrahydrocannabinol and anandamide on a battery of cognition-related behavior in nonhuman primates. J. Pharm. Exp. 2016, 357, 125-133. [CrossRef]

19. Panlilio, L.V.; Thorndike, E.B.; Nikas, S.P.; Alapafuja, S.O.; Bandiera, T.; Cravatt, B.F.; Makriyannis, A.; Piomelli, D.; Goldberg, S.R.; Justinova, Z. Effects of fatty acid amide hydrolase (FAAH) inhibitors on working memory in rats. Psychopharmacol. (Berl) 2016, 233, 1879-1888. [CrossRef]

20. Contino, M.; Capparelli, E.; Colabufo, N.A.; Bush, A.I. Editorial: The CB2 cannabinoid system: A new strategy in neurodegenerative disorder and neuroinflammation. Front Neurosci. 2017, 11, 196. [CrossRef]

21. Guindon, J.; Hohmann, A.G. Cannabinoid CB2 receptors: A therapeutic target for the treatment of inflammatory and neuropathic pain. Br. J. Pharm. 2008, 153, 319-334. [CrossRef] [PubMed] 
22. Zarruk, J.G.; Fernandez-Lopez, D.; Garcia-Yebenes, I.; Garcia-Gutierrez, M.S.; Vivancos, J.; Nombela, F.; Torres, M.; Burguete, M.C.; Manzanares, J.; Lizasoain, I.; et al. Cannabinoid type 2 receptor activation downregulates stroke-induced classic and alternative brain macrophage/microglial activation concomitant to neuroprotection. Stroke 2012, 43, 211-219. [CrossRef] [PubMed]

23. Amenta, P.S.; Jallo, J.I.; Tuma, R.F.; Elliott, M.B. A cannabinoid type 2 receptor agonist attenuates blood-brain barrier damage and neurodegeneration in a murine model of traumatic brain injury. J. Neurosci. Res. 2012, 90, 2293-2305. [CrossRef] [PubMed]

24. Velasco, G.; Sanchez, C.; Guzman, M. Towards the use of cannabinoids as antitumour agents. Nat. Rev. Cancer 2012, 12, 436-444. [CrossRef] [PubMed]

25. Chakravarti, B.; Ravi, J.; Ganju, R.K. Cannabinoids as therapeutic agents in cancer: Current status and future implications. Oncotarget 2014, 5, 5852-5872. [CrossRef] [PubMed]

26. Velasco, G.; Hernandez-Tiedra, S.; Davila, D.; Lorente, M. The use of cannabinoids as anticancer agents. Prog. Neuropsychopharmacol. Biol. Psychiatry 2016, 64, 259-266. [CrossRef]

27. Khanolkar, A.D.; Lu, D.; Ibrahim, M.; Duclos, R.I., Jr.; Thakur, G.A.; Malan, T.P., Jr.; Porreca, F.; Veerappan, V.; Tian, X.; George, C.; et al. Cannabilactones: A novel class of CB2 selective agonists with peripheral analgesic activity. J. Med. Chem. 2007, 50, 6493-6500. [CrossRef]

28. Deng, L.; Guindon, J.; Cornett, B.L.; Makriyannis, A.; Mackie, K.; Hohmann, A.G. Chronic cannabinoid receptor 2 activation reverses paclitaxel neuropathy without tolerance or cannabinoid receptor 1-dependent withdrawal. Biol. Psychiatry 2015, 77, 475-487. [CrossRef]

29. Rahn, E.J.; Deng, L.; Thakur, G.A.; Vemuri, K.; Zvonok, A.M.; Lai, Y.Y.; Makriyannis, A.; Hohmann, A.G. Prophylactic cannabinoid administration blocks the development of paclitaxel-induced neuropathic nociception during analgesic treatment and following cessation of drug delivery. Mol. Pain. 2014, 10, 27. [CrossRef]

30. Dhopeshwarkar, A.; Mackie, K. Functional selectivity of CB2 cannabinoid receptor ligands at a canonical and noncanonical pathway. J. Pharm. Exp. 2016, 358, 342-351. [CrossRef]

31. Li, A.L.; Lin, X.Y.; Dhopeshwarkar, A.S.; Thomaz, A.C.; Carey, L.M.; Liu, Y.P.; Nikas, S.P.; Makriyannis, A.; Mackie, K.; Hohmann, A.G. Cannabinoid CB2 agonist AM1710 differentially suppresses distinct pathological pain states and attenuates morphine tolerance and withdrawal. Mol. Pharm. 2019, 95, 155-168. [CrossRef] [PubMed]

32. Rahn, E.J.; Thakur, G.A.; Wood, J.A.T.; Zvonok, A.M.; Makriyannis, A.; Hohmann, A.G. Pharmacological characterization of AM1710, a putative cannabinoid CB2 agonist from the cannabilactone class: Antinociception without central nervous system side-effects. Pharm. Biochem. Behav. 2011, 98, 493-502. [CrossRef] [PubMed]

33. Dhopeshwarkar, A.; Murataeva, N.; Makriyannis, A.; Straiker, A.; Mackie, K. Two janus cannabinoids that are both CB2 agonists and CB1 antagonists. J. Pharm. Exp. 2017, 360, 300-311. [CrossRef] [PubMed]

34. Papahatjis, D.P.; Nahmias, V.R.; Nikas, S.P.; Andreou, T.; Alapafuja, S.O.; Tsotinis, A.; Guo, J.; Fan, P.; Makriyannis, A. C1'-cycloalkyl side chain pharmacophore in tetrahydrocannabinols. J. Med. Chem. 2007, 50, 4048-4060. [CrossRef] [PubMed]

35. Papahatjis, D.P.; Nikas, S.P.; Kourouli, T.; Chari, R.; Xu, W.; Pertwee, R.G.; Makriyannis, A. Pharmacophoric requirements for the cannabinoid side chain. Probing the cannabinoid receptor subsite at C1'. J. Med. Chem. 2003, 46, 3221-3229. [CrossRef]

36. Ho, T.C.; Shimada, N.; Tius, M.A.; Nikas, S.P.; Zhang, W.; Makriyannis, A. C1'-azacycloalkyl hexahydrocannabinols. J. Org. Chem. 2017, 82, 7839-7849. [CrossRef] [PubMed]

37. Nikas, S.P.; Alapafuja, S.O.; Papanastasiou, I.; Paronis, C.A.; Shukla, V.G.; Papahatjis, D.P.; Bowman, A.L.; Halikhedkar, A.; Han, X.; Makriyannis, A. Novel 1',1 '-chain substituted hexahydrocannabinols: 9beta-1-hydroxy-3-(1-hexyl-cyclobut-l-yl)hexahydrocannabinol (AM2389) a highly potent cannabinoid receptor 1 (CB1) agonist. J. Med. Chem. 2010, 53, 6996-7010. [CrossRef]

38. Nikas, S.P.; Sharma, R.; Paronis, C.A.; Kulkarni, S.; Thakur, G.A.; Hurst, D.; Wood, J.T.; Gifford, R.S.; Rajarshi, G.; Liu, Y.; et al. Probing the carboxyester side chain in controlled deactivation (-)-delta(8)-tetrahydrocannabinols. J. Med. Chem. 2015, 58, 665-681. [CrossRef]

39. Papahatjis, D.P.; Nikas, S.P.; Andreou, T.; Makriyannis, A. Novel 1' $1^{\prime}, 1^{\prime}$-chain substituted delta(8)-tetrahydrocannabinols. Bioorg. Med. Chem. Lett. 2002, 12, 3583-3586. [CrossRef] 
40. Hajduk, P.J.; Bures, M.; Praestgaard, J.; Fesik, S.W. Privileged molecules for protein binding identified from NMR-based screening. J. Med. Chem. 2000, 43, 3443-3447. [CrossRef]

41. Horton, D.A.; Bourne, G.T.; Smythe, M.L. The combinatorial synthesis of bicyclic privileged structures or privileged substructures. Chem. Rev. 2003, 103, 893-930. [CrossRef] [PubMed]

42. Severinsen, R.; Bourne, G.T.; Tran, T.T.; Ankersen, M.; Begtrup, M.; Smythe, M.L. Library of biphenyl privileged substructures using a safety-catch linker approach. J. Comb. Chem. 2008, 10, 557-566. [CrossRef] [PubMed]

43. Luning, U.; Abbass, M.; Fahrenkrug, F. A facile route to aryl-substituted 1,10-phenanthrolines by means of Suzuki coupling reactions between substituted areneboronic acids and halogeno-1,10-phenanthrolines. Eur. J. Org. Chem. 2002, 3294-3303. [CrossRef]

44. Nichols, D.E.; Dyer, D.C. Lipophilicity and serotonin agonist activity in a series of 4-substituted mescaline analogs. J. Med. Chem. 1977, 20, 299-301. [CrossRef] [PubMed]

45. Calzada, J.G.; Hooz, J. Geranyl chloride. Org. Synth. 1974, 54, 63.

46. Takahashi, T.; Ikeda, H.; Tsuji, J. Synthesis of ( \pm )-dimethyl curvularin based on palladium-catalyzed carbonylation of 3,5-dimethoxybenzyl chloride using a butadiene telomer as a building block. Tetrahedron Lett. 1980, 21, 3885-3888. [CrossRef]

47. Papahatjis, D.P.; Nikas, S.P.; Tsotinis, A.; Vlachou, M.; Makriyannis, A. A new ring formation methodology for the synthesis of conformationally restricted bioactive molecules. Chem. Lett. 2001, 3, 192-193. [CrossRef]

48. Yoon, M.N.; Gyoung, Y.S. Reaction of diisobutyaluminum hydride with selected organic compounds containing representative functional groups. J. Org. Chem. 1985, 50, 2443-2450. [CrossRef]

49. Schweizer, E.E.; Bach, R.D. Phosphonium Salts. II. 2-Bromophenetole and triphenylphosphorus as novel phosphonioethylation precursors. J. Org. Chem. 1964, 29, 1746-1751. [CrossRef]

50. Lattanzi, A.; Orelli, L.R.; Barone, P.; Massa, A.; Iannece, P.; Scettri, A. Convenient procedure of Horner-Wadsworth-Emmons olefination for the synthesis of simple and functionalized $\alpha, \beta$-unsaturated nitriles. Tetrahedron Lett. 2003, 44, 1333-1337. [CrossRef]

51. Bottin-Strzalko, T.; Corset, J.; Froment, F.; Ponet, M.J.; Seyden-Penne, J.; Simmonin, M.P. Structural studies of carbanionic species alpha to a phosphoryl group. The anion of diethyl[(carbomethoxy)methyl]phosphonate. Comparison with phosphorous-ylidic esters and acetoacetic esters anions. J. Org. Chem. 1980, 45, 1270-1276. [CrossRef]

52. Gushurst, A.J.; Jorgensen, W.L. Computer-assisted mechanistic evaluation of organic reactions. 14. Reactions of sulfur and phosphorous ylides, iminophosphoranes, and $\mathrm{P}=\mathrm{X}$-activated anions. J. Org. Chem. 1988, 53, 3397-3408. [CrossRef]

53. Clase, J.A.; Money, T. An enantiospecific route to C,D ring synthons for steroid synthesis. Can. J. Chem. 1992, 70, 1537-1544. [CrossRef]

54. Srebnik, M.; Mechoulam, R.; Yona, I. Halogenation of phenols and phenyl ethers with potassium halides in the presence of 18-crown-6 on oxidation with m-chloroperbenzoic acid. J. Chem. Soc. Perkins Trans 1 1987, 7 , 1423-1427. [CrossRef]

55. Alo, B.I.; Kandil, A.; Patil, P.A.; Sharp, M.J.; Siddiqui, M.A.; Snieckus, V.; Josephy, P.D. Sequential directed ortho metallation-boronic acid cross-coupling reactions. A general regiospecific route to oxygenated dibenzo[b,d]pyran-6-ones related to ellagic acid. J. Org. Chem. 1991, 56, 3763-3768. [CrossRef]

56. Lai, X. Biaryl ligands as probes for proteins of the endocannabinoid system. Ph.D. Thesis, University of Connecticut, Storrs, CT, USA, 2005.

57. Kulkarni, S.; Nikas, S.P.; Sharma, R.; Jiang, S.; Paronis, C.A.; Leonard, M.Z.; Zhang, B.; Honrao, C.; Mallipeddi, S.; Raghav, J.G.; et al. Novel C-ring-hydroxy-substituted controlled deactivation cannabinergic analogues. J. Med. Chem. 2016, 59, 6903-6919. [CrossRef] [PubMed]

58. Liu, Y.; Ji, L.; Eno, M.; Kudalkar, S.; Li, A.L.; Schimpgen, M.; Benchama, O.; Morales, P.; Xu, S.; Hurst, D.; et al. (R)-N-(1-Methyl-2-hydroxyethyl)-13-(S)-methyl-arachidonamide (AMG315): A novel chiral potent endocannabinoid ligand with stability to metabolizing enzymes. J. Med. Chem. 2018, 61, 8639-8657. [CrossRef] [PubMed]

59. Cheng, Y.; Prusoff, W.H. Relationship between the inhibition constant (K1) and the concentration of inhibitor which causes 50 per cent inhibition (I50) of an enzymatic reaction. Biochem. Pharm. 1973, 22, 3099-3108. 
60. Ogawa, G.; Tius, M.A.; Zhou, H.; Nikas, S.P.; Halikhedkar, A.; Mallipeddi, S.; Makriyannis, A. 3'-functionalized adamantyl cannabinoid receptor probes. J. Med. Chem. 2015, 58, 3104-3116. [CrossRef]

Sample Availability: Samples of the compounds are not available from the authors. 